
25 Research Square
Preprints are preliminary reports that have not undergone peer review.
They should not be considered conclusive, used to inform clinical practice, or referenced by the media as validated information.

\title{
Termination of Pregnancy for Fetal Anomaly: A Systematic Review of the Healthcare Experiences and Needs of Parents
}

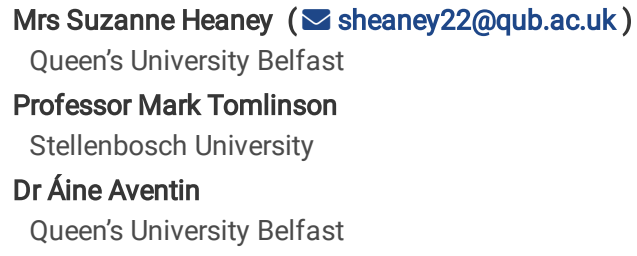

\section{Research Article}

Keywords: Termination of pregnancy, fetal anomaly, congenital abnormalities, TOPFA, abortion, feticide, healthcare experience, healthcare needs, parents, systematic review

Posted Date: October 6th, 2021

DOI: https://doi.org/10.21203/rs.3.rs-930061/v1

License: (c) (1) This work is licensed under a Creative Commons Attribution 4.0 International License. Read Full License 


\section{Abstract}

Background

Improved technology and advances in clinical testing have resulted in increased detection rates of congenital anomalies during pregnancy, resulting in more parents being confronted with the possibility of terminating a pregnancy for this reason. There is a large body of research on the psychological experience and impact of terminating a pregnancy for fetal anomaly. However, there remains a lack of evidence on the holistic healthcare experience of parents in this situation. To develop a comprehensive understanding of the healthcare experience and needs of parents, this systematic review sought to summarise and appraise the literature on parents' experiences following a termination of pregnancy for fetal anomaly.

Review Question:

What are the healthcare experiences and needs of parents who undergo a termination of pregnancy following an antenatal diagnosis of a fetal anomaly?

Methods

A systematic review was undertaken with searches completed across six multi-disciplinary electronic databases (Medline, Embase, PsycINFO, CINAHL, Web of Science, and Cochrane). Eligible records were qualitative, quantitative or mixed methods studies, published between January 2010 and August 2021 , reporting the results of primary data on the healthcare experiences or healthcare needs in relation to termination of pregnancy for fetal anomaly for either or both parents. Findings were synthesised using Thematic Analysis.

Results

A total of 30 records were selected for inclusion in this review of which 24 were qualitative, five quantitative and one mixed-methods. Five overarching themes emerged from the synthesis of findings: (1) Context of Care, (2) Person-centred Care, (3) Compassionate Care, (4) Co-ordinated Care, and (5) Inclusive Care.

Conclusion

Compassionate healthcare professionals who provide non-judgemental and sensitive care can impact positively on parents' satisfaction with the care they receive. A well organised and co-ordinated healthcare system is needed to provide an effective and high-quality service.

Registration:

PROSPERO registration number: CRD42020175970

\section{Introduction}

Congenital anomalies are defined as structural or functional abnormalities that occur prior to birth (World Health Organization (WHO), 2020a), often resulting in high levels of morbidity and mortality (Lozano et al., 2012; Modell et al. 2012; Sitkin et al., 2015; WHO, 2020b). Improved technology and advances in clinical testing have resulted in increased detection rates of congenital anomalies during pregnancy (Boyd et al., 2008; Daum et al., 2019; Ganesamoorthy et al., 2013; Pan et al., 2018). This is mainly seen in high-income countries (HICs) where sufficient resources and equipment enables increased routine antenatal testing and screening by adequately trained health professionals (Bricker et al., 2015; Jiwani et al., 2020; Public Health England, 2013; Whitworth et al., 2015; WHO, 2016). However, while detection rates have improved, few in-utero treatments are available for major anomalies (Adzick et al., 2011; Fisher and Lafarge, 2015; Zwiers et al., 2018), leaving parents with limited options following diagnosis. They can continue with the pregnancy, or in the case of the detection of a fetal anomaly, they can request a Termination of Pregnancy (TOP) in the 113 (out of $199(57 \%)$ ) countries and territories around the world where it is legal to do so (Boyd et al., 2008; Maurice et al., 2019; Remez et al., 2020).

In countries where TOP is legal, there are often variations with the definition and clauses of what types of anomalies are included to be able to access a termination of pregnancy for fetal anomaly (TOPFA). For example, in the United Kingdom (UK) the law stipulates that where the anomaly represents a 'substantial risk' that the child who would be born would be 'seriously handicapped', would be accepted as grounds (Ground E) for a TOPFA (The Abortion Act 1967 (as amended in the Human Fertilisation and Embryology Act, 1990 (House of Commons, 1990)). Conversely, in the Republic of Ireland (in accordance with the Health (Regulation of Termination of Pregnancy) Act, 2018) two medical practitioners must be of the agreed opinion that the baby will die during pregnancy, labour or within twenty-eight days of birth for a TOPFA to be sanctioned (Institute of Obstetricians and Gynecologists, 2019). In the United States, access to TOP varies from State to State, due to differing government, healthcare provider and medical insurance restrictions (American College of Obstetrics and Gynecologists, 2020). Six States entirely prohibit TOPFA, while a further four require mandatory counselling on available perinatal hospice services before it can be performed (Guttmacher Institute, 2021). Worldwide, of the 86 countries and territories where TOPFA is prohibited, $81 \%$ are low- and middle-income countries (LMICs)(Remez et al., 2020).

Legal differences regarding the definition or threshold of congenital anomalies considered severe enough to access TOPFA, means that obtaining accurate data pertaining to TOPFA is challenging (Berer, 2017; Myers and Seif, 2010; Singh et al., 2017). European figures for TOPFA suggest a prevalence rate of 4.6 per 1,000 births (Boyle et al., 2018). In the UK, over $70 \%$ of congenital anomalies are detected during pregnancy, and, of those, around $37 \%$ will result in a TOPFA (Public Health England, 2020). Government figures for England and Wales reported that, in 2019, 3,183 TOPFAs were carried out, in the context of 640,370 livebirths and 2,522 stillbirths in the same year (Department of Health and Social Care, 2020; Office for National Statistics, 2020). However, groups working in this area of healthcare, such as the British Pregnancy Advisory Service (BPAS) and Antenatal Results and Choices suggest that actual rates of TOPFA are much higher (BPAS, 2015). A possible reason for the disparity in figures could be that in the UK if a TOP is carried out under 24 weeks it could be

Page $2 / 21$ 
recorded under Ground $\mathrm{C}$ of the Abortion Act (the risk to a woman's physical or mental health is greater than if she continued the pregnancy) (House of Commons, 1990). Figures from 2019 state $98 \%$ of all abortions in England and Wales were performed under Ground C (Department of Health and Social Care, 2020).

Existing reviews have explored the psychological experience and impact of TOPFA (Deas, 2017; Statham et al., 2000; Statham, 2002; Steinberg, 2011; Sullivan and De Faoite, 2017; Wool, 2011) yet limited consideration of the holistic healthcare experience of parents. One exception is Lafarge et al.'s (2014), study which offers a more holistic view and interpretation of the experience of TOPFA via a meta-ethnography of women's experiences. This study was not, however, specifically focused on healthcare experiences and did not include partners, an issue that is seen across the field of perinatal loss (Badenhorst et al., 2006; Due et al., 2017; McCreight, 2004; O'Leary and Thorwick, 2006). Another qualitative review explores the labour and birth experiences of women who have had a TOPFA (Jones et al., 2017) and while offering useful insights, is only one part of the overall healthcare experience. Another review of the needs of women who have experienced a TOPFA did report needs related to the healthcare system, however it did not use systematic review methodology (Kamranpour et al., 2018).

The dearth of research looking at the entire TOPFA healthcare experience, as well as from both parents' experience warrants further investigation. Thus, the overall aims of this literature review were to (a) synthesise findings from the international literature on the healthcare experiences and needs of parents who undergo a termination of pregnancy following an antenatal diagnosis of a fetal anomaly, (b) carry out a thematic analysis of the evidence, and (c) provide a comprehensive narrative synthesis, focusing on the views, experiences, feelings, opinions and needs of both parents.

\section{Methods}

This mixed-methods systematic review adhered to a PROSPERO pre-registered protocol (CRD42020175970) (Heaney et al., 2020). It was conducted using Covidence Systematic Review Software (2019), NVivo Version 12 for Windows (QSR International, 2018) and in accordance with PRISMA 2020 guidelines (Page et al. 2021).

\section{Search Strategy And Sources}

The search strategy was developed by reviewing and extracting search terms from existing relevant reviews (Jones et al., 2017; Lafarge et al., 2014) or published studies with a similar sample (Fisher and Lafarge, 2015; Hanschmidt et al., 2018a, b; Hyatt, 2019). A combination of Medical Subject Headings $(\mathrm{MeSH})$ and keyword search terms were employed, following consultation with a search specialist. Search terms used were structured within the PICO framework (see Table 1) (Raich and Skelly, 2013).

Table 1

PICO Framework Search Terms

\begin{tabular}{|c|c|c|}
\hline $\begin{array}{l}\text { PICO } \\
\text { Acronym }\end{array}$ & MeSH search terms & Additional search terms \\
\hline Population & $\begin{array}{l}\text { Parents, Parenting, Pregnant } \\
\text { Women, Men, Postpartum } \\
\text { Period, Peripartum } \\
\text { Period, Women's Health, Men's } \\
\text { Health, Maternal-Fetal } \\
\text { Relations }\end{array}$ & $\begin{array}{l}\text { Famil*, Parent*, Mother, Father, Wom?n, M?n, M?m, Dad, Maternal, Paternal, Pregnant Wom?n, Pregnant } \\
\text { Person, Pregnan* }\end{array}$ \\
\hline Intervention & $\begin{array}{l}\text { Aborted Fetus, Abortion } \\
\text { Applicants, Abortion, } \\
\text { Eugenic, Abortion, Induced }\end{array}$ & $\begin{array}{l}\text { Abortion, Termination, Fet?cide, Medical Abortion, Medical Miscarriage, Medical Termination, Induced } \\
\text { Abortion, Termination of Pregnancy, TOP }\end{array}$ \\
\hline Condition & $\begin{array}{l}\text { Fetal Viability, Congenital } \\
\text { Abnormalities, Congenital, } \\
\text { Hereditary, and Neonatal } \\
\text { Diseases and Abnormalities }\end{array}$ & $\begin{array}{l}\text { F? etal Anomal*, Fatal F?etal Anomal*, Incompatible with life, Abnormality, Anomal* Scan, Life Limiting, } \\
\text { Fatal Anomal*, Gene? Condition, Gene? Disorder, Congenital Anomal*, Congenital malformation, FA, FFA }\end{array}$ \\
\hline Outcome & & $\begin{array}{l}\text { Experience*, Opinion*, View*, Need*, Health?, Healthcare, Health service, Support, Care, Access*, Travel*, } \\
\text { Financ*, Cost, Stigma, Psychological outcome*, Physical outcome*, Patient satisfaction, Social support, } \\
\text { Mental health, Family, Family relations, Family conflict, Maternal behavio?r, Paternal behavio?r, Life } \\
\text { Change Events, Trauma?, Stress disorders, Life stress event\$.tw, Health?related quality of life.tw, Parent } \\
\text { morbidity.tw, Satisfaction with care.tw }\end{array}$ \\
\hline
\end{tabular}

Six multi-disciplinary electronic databases (Medline, Embase, PsycINFO, CINAHL, Web of Science, and Cochrane) were searched on 23rd March 2020 with an updated search carried out on 6th August 2021 using the search terms in Table 1. Beyond the databases, lateral and manual searches were also conducted. The strategy for this included searches in: grey literature databases (Open Grey, BASE, GreyNet); clinical trial registers (Clinicaltrials.gov, ISRCTN Registry, NIHR UK, WHO ICTRP); web searches (Google, Google Scholar, Grey Literature Report, National Health Service (NHS) Evidence); dissertation/thesis searches (OATD International, ProQuest); and through examination of the reference lists of included studies. The lead author, SH carried out all searches.

\section{Study Selection}

Included studies were of qualitative, quantitative or mixed methods design, published between 1st January 2010 and 6 th August 2021 , reporting the results of primary data on the healthcare experiences or healthcare needs in relation to TOPFA for either or both parents. No limitation was set on the type of anomaly or 
study location. Exclusion criteria included: studies not published in English; non-empirical studies, such as case reports, opinion pieces or reviews; and studies reporting experience of TOP for a reason other than fetal anomaly. Studies were also excluded if they only reported health professionals' or other family members' experiences of TOPFA. SH screened all records and ÁA independently screened a randomly selected $10 \%(n=9)$ of the full text records for eligibility.

\section{Quality Appraisal}

While acknowledging the lack of consensus relating to how, what (and perhaps if) qualitative research should be quality assessed (Hannes et al., 2010; Murphy et al., 1998; Spencer et al., 2003), we carried out quality assessment for the purposes of transparency (Thomas and Harden, 2008). The Mixed Methods Appraisal Tool (MMAT) Version 2018 (Hong et al., 2018) was used given its value for appraising the quality of a variety of study designs (Pluye et al., 2009). The quality of studies was evaluated primarily on the appropriateness of the study design and interpretation of the results substantiated by findings and data. As per the guidelines of the tool no overall score was calculated. In line with MMAT guidelines, two reviewers (SH and ÁA) were independently involved in the appraisal process (Hong et al., 2018). SH reviewed all of the included studies and ÁA quality assured a random sample (10\%) of the records.

\section{Data Extraction And Synthesis}

Descriptive data were initially extracted by SH into the Covidence Systematic Review Software (2019), using a pre-designed data extraction form to collate and manage the information. ÁA cross-checked this information. The descriptive data extracted summarised the key characteristics of the selected studies and included: year of publication, the country where the research was conducted, study design, participants, data collection methods and analysis and study aims (see Table 2). 
Table 2

Characteristics of Included Studies

\begin{tabular}{|c|c|c|c|c|c|}
\hline Study & Country & Participants & $\begin{array}{l}\text { Data } \\
\text { Collection }\end{array}$ & Methodology & Study Aim \\
\hline $\begin{array}{l}\text { Asplin et al., } \\
2014 \\
\mathbf{1}\end{array}$ & Sweden & 11 women & $\begin{array}{l}\text { Semi- } \\
\text { structured } \\
\text { interviews }\end{array}$ & $\begin{array}{l}\text { Qualitative } \\
\text { Exploratory } \\
\text { Descriptive Design } \\
\text { Retrospective }\end{array}$ & $\begin{array}{l}\text { The aim of the study was to explore what women who have had a } \\
\text { pregnancy termination due to a detected fetal malformation } \\
\text { perceive as being important in their encounters with caregivers for } \\
\text { promoting their healthy adjustment and well-being. }\end{array}$ \\
\hline $\begin{array}{l}\text { Atienza- } \\
\text { Carrasco et } \\
\text { al., } 2020 \\
\mathbf{2}\end{array}$ & Spain & 27 women & $\begin{array}{l}\text { Nonparticipant } \\
\text { observation } \\
\text { Semi- } \\
\text { structured } \\
\text { interviews }\end{array}$ & $\begin{array}{l}\text { Qualitative } \\
\text { Phenomenological } \\
\text { Approach } \\
\text { Retrospective }\end{array}$ & $\begin{array}{l}\text { To determine and describe the experiences of pregnant women } \\
\text { who receive a diagnosis of chromosomopathy and/or foetal } \\
\text { malformation during a prenatal check-up and who decide to } \\
\text { legally terminate the pregnancy. }\end{array}$ \\
\hline $\begin{array}{l}\text { Carlsson et } \\
\text { al., } 2016 \\
\mathbf{3}\end{array}$ & Sweden & $\begin{array}{l}112 \text { women } \\
1 \text { man } \\
9 \text { not } \\
\text { disclosed }\end{array}$ & $\begin{array}{l}\text { Cross- } \\
\text { sectional } \\
\text { study of } \\
\text { messages in } \\
\text { virtual } \\
\text { communities }\end{array}$ & $\begin{array}{l}\text { Qualitative } \\
\text { Content analysis } \\
\text { Retrospective }\end{array}$ & $\begin{array}{l}\text { To explore experiences described by posters in Swedish virtual } \\
\text { communities before, during and after termination of pregnancy } \\
\text { due to a fetal anomaly. }\end{array}$ \\
\hline $\begin{array}{l}\text { Chaloumsuk, } \\
2013 \\
4\end{array}$ & Thailand & 12 women & $\begin{array}{l}\text { Unstructured } \\
\text { interviews }\end{array}$ & $\begin{array}{l}\text { Qualitative } \\
\text { Interpretive } \\
\text { phenomenology } \\
\text { Retrospective }\end{array}$ & $\begin{array}{l}\text { This study aimed to gain an understanding of experiences of } \\
\text { miscarriage and termination of pregnancy for fetal anomaly } \\
\text { among a group of Thai women }\end{array}$ \\
\hline $\begin{array}{l}\text { Cowchock et } \\
\text { al., } 2011 \\
\mathbf{5}\end{array}$ & USA & $\begin{array}{l}9 \text { women } \\
5 \text { men }\end{array}$ & Survey & $\begin{array}{l}\text { Quantitative } \\
\text { Survey } \\
\text { Retrospective }\end{array}$ & $\begin{array}{l}\text { The spiritual needs of couples ( } 9 \text { mothers and } 5 \text { fathers) who were } \\
\text { planning to terminate wanted second trimester pregnancies } \\
\text { because of serious fetal anomalies were surveyed. }\end{array}$ \\
\hline $\begin{array}{l}\text { Dekkers et } \\
\text { al., } 2019 \\
6\end{array}$ & $\begin{array}{l}\text { The } \\
\text { Netherlands }\end{array}$ & $\begin{array}{l}76 \text { women } \\
36 \text { partners }\end{array}$ & $\begin{array}{l}\text { Semi- } \\
\text { structured } \\
\text { online } \\
\text { questionnaire }\end{array}$ & $\begin{array}{l}\text { Quantitative } \\
\text { Cross-sectional } \\
\text { Retrospective } \\
\text { cohort study } \\
\text { Retrospective }\end{array}$ & $\begin{array}{l}\text { To investigate, from the perspective of women and partners, at } \\
\text { what stage of a termination of pregnancy (TOP) for fetal } \\
\text { anomalies psychosocial care (PSC)is most meaningful, what } \\
\text { topics should be discussed, and who should provide PSC }\end{array}$ \\
\hline $\begin{array}{l}\text { Desrochers, } \\
2011 \\
7\end{array}$ & USA & 7 men & $\begin{array}{l}\text { Semi- } \\
\text { structured } \\
\text { interviews }\end{array}$ & $\begin{array}{l}\text { Qualitative } \\
\text { Retrospective }\end{array}$ & $\begin{array}{l}\text { The purpose of this study was to explore the thoughts and } \\
\text { feelings of fathers throughout the experience including the initial } \\
\text { diagnosis and the decision-making process, as well as the journey } \\
\text { of grieving and coping. }\end{array}$ \\
\hline $\begin{array}{l}\text { Fisher and } \\
\text { Lafarge, } \\
2015 \\
\mathbf{8}\end{array}$ & $\begin{array}{l}\text { UK } \\
\text { (England) }\end{array}$ & 361 women & $\begin{array}{l}\text { Cross } \\
\text { sectional } \\
\text { online survey }\end{array}$ & $\begin{array}{l}\text { Qualitative } \\
\text { Retrospective }\end{array}$ & $\begin{array}{l}\text { This study investigated women's experience of care when } \\
\text { undergoing termination of pregnancy for fetal anomaly (TOPFA) }\end{array}$ \\
\hline $\begin{array}{l}\text { Fisher et al., } \\
2015 \\
\mathbf{9}\end{array}$ & $\begin{array}{l}\text { UK } \\
\text { (England) }\end{array}$ & 351 women & $\begin{array}{l}\text { Self- } \\
\text { administered } \\
\text { online } \\
\text { questionnaire }\end{array}$ & $\begin{array}{l}\text { Quantitative } \\
\text { Retrospective }\end{array}$ & $\begin{array}{l}\text { We investigated whether women are offered a choice of method, } \\
\text { by surveying members of a UK parent support organisation. }\end{array}$ \\
\hline $\begin{array}{l}\text { Gawron et } \\
\text { al., } 2013 \\
10\end{array}$ & USA & 30 women & $\begin{array}{l}\text { Semi- } \\
\text { structured } \\
\text { interviews }\end{array}$ & $\begin{array}{l}\text { Qualitative } \\
\text { Latent content } \\
\text { analysis } \\
\text { Retrospective }\end{array}$ & $\begin{array}{l}\text { The objectives of this study were to explore reasons for pregnancy } \\
\text { termination timing among patients with fetal abnormalities by } \\
\text { analyzing their pregnancy care timeline and their decision-making } \\
\text { process. }\end{array}$ \\
\hline $\begin{array}{l}\text { Hassan, } \\
2015 \\
11\end{array}$ & $\begin{array}{l}\text { Canada \& } \\
\text { USA }\end{array}$ & 10 women & $\begin{array}{l}\text { Un-structured } \\
\text { in-depth } \\
\text { interviews }\end{array}$ & $\begin{array}{l}\text { Qualitative } \\
\text { Interpretive } \\
\text { phenomenology } \\
\text { Retrospective }\end{array}$ & $\begin{array}{l}\text { To gain an in-depth understanding of the long-term experiences of } \\
\text { women who terminated their pregnancy for fetal abnormalities } \\
\text { and reveal the meanings embedded in their experiences. }\end{array}$ \\
\hline $\begin{array}{l}\text { Irani et al., } \\
2019 \\
\mathbf{1 2}\end{array}$ & Iran & 7 women & $\begin{array}{l}\text { Semi- } \\
\text { structured in- } \\
\text { depth } \\
\text { interviews }\end{array}$ & $\begin{array}{l}\text { Qualitative } \\
\text { Conventional } \\
\text { content analysis } \\
\text { Retrospective }\end{array}$ & $\begin{array}{l}\text { To explore the emotional and cognitive experiences of pregnant } \\
\text { women following prenatal diagnosis of fetal anomalies in } \\
\text { Mashhad, Iran. }\end{array}$ \\
\hline
\end{tabular}




\begin{tabular}{|c|c|c|c|c|c|}
\hline Study & Country & Participants & $\begin{array}{l}\text { Data } \\
\text { Collection }\end{array}$ & Methodology & Study Aim \\
\hline $\begin{array}{l}\text { Kamranpour } \\
\text { et al., } 2020 \\
13\end{array}$ & Iran & $\begin{array}{l}25 \text { women } \\
2 \text { men }\end{array}$ & $\begin{array}{l}\text { In depth semi- } \\
\text { structured } \\
\text { interviews }\end{array}$ & $\begin{array}{l}\text { Qualitative } \\
\text { Conventional } \\
\text { qualitative content } \\
\text { analysis } \\
\text { Retrospective }\end{array}$ & $\begin{array}{l}\text { This study aimed to explore the needs related to the health system } \\
\text { in women with experience of pregnancy termination due to fetal } \\
\text { anomalies. }\end{array}$ \\
\hline $\begin{array}{l}\text { Kamranpour } \\
\text { et al., } 2021 \\
14\end{array}$ & Iran & $\begin{array}{l}25 \text { women } \\
2 \text { men }\end{array}$ & $\begin{array}{l}\text { In depth semi- } \\
\text { structured } \\
\text { interviews }\end{array}$ & $\begin{array}{l}\text { Qualitative } \\
\text { Conventional } \\
\text { qualitative content } \\
\text { analysis } \\
\text { Retrospective }\end{array}$ & $\begin{array}{l}\text { This study aimed to explore the informational and educational } \\
\text { needs of women who have experienced pregnancy termination } \\
\text { because of fetal anomalies. }\end{array}$ \\
\hline $\begin{array}{l}\text { Kecir et al., } \\
2020 \\
15\end{array}$ & France & 8 men & $\begin{array}{l}\text { Semi- } \\
\text { structured } \\
\text { interviews }\end{array}$ & $\begin{array}{l}\text { Qualitative } \\
\text { Retrospective }\end{array}$ & $\begin{array}{l}\text { Aim of this qualitative study is to describe how fathers perceive } \\
\text { the TOP, their feelings about caregivers and their strategies for } \\
\text { coping. }\end{array}$ \\
\hline $\begin{array}{l}\text { Koponen et } \\
\text { al., } 2013 \\
16\end{array}$ & Finland & 8 women & $\begin{array}{l}\text { Written } \\
\text { accounts }\end{array}$ & $\begin{array}{l}\text { Qualitative } \\
\text { Linguistic } \\
\text { discourse analysis } \\
\text { Retrospective }\end{array}$ & $\begin{array}{l}\text { This study explores the construction of parental and professional } \\
\text { agency in the written accounts by women who have undergone } \\
\text { selective abortion. }\end{array}$ \\
\hline $\begin{array}{l}\text { Lafarge et } \\
\text { al., } 2013 \\
17\end{array}$ & UK & 27 women & Online survey & $\begin{array}{l}\text { Qualitative } \\
\text { Interpretative } \\
\text { phenomenological } \\
\text { analysis } \\
\text { Retrospective }\end{array}$ & $\begin{array}{l}\text { To examine the coping strategies women use both during and } \\
\text { after a TFA procedure. }\end{array}$ \\
\hline $\begin{array}{l}\text { Lafarge et } \\
\text { al., } 2019 \\
18\end{array}$ & $\begin{array}{l}\text { UK } \\
\text { (England) } \\
\text { and France }\end{array}$ & $\begin{array}{l}27 \text { women } \\
\text { (England) } \\
17 \text { women } \\
\text { (France) } \\
\text { *UK sample } \\
\text { is the same } \\
\text { as study } 17\end{array}$ & $\begin{array}{l}\text { Online survey } \\
\text { (open-ended } \\
\text { questions) } \\
\text { Interviews }\end{array}$ & $\begin{array}{l}\text { Qualitative } \\
\text { Thematic analysis } \\
\text { Retrospective }\end{array}$ & $\begin{array}{l}\text { The aim of this article is to demonstrate the relevance of } \\
\text { ambivalence to the experience of TFA. Data from two qualitative } \\
\text { studies conducted with women who had undergone TFA, one in } \\
\text { England, the other in France, have been used to convey and } \\
\text { illustrate the ambivalence that characterises the TFA experience. }\end{array}$ \\
\hline $\begin{array}{l}\text { Leichtentritt, } \\
2011 \\
19\end{array}$ & Israel & 13 women & $\begin{array}{l}\text { Semi- } \\
\text { structured in- } \\
\text { depth } \\
\text { interviews }\end{array}$ & $\begin{array}{l}\text { Qualitative } \\
\text { Narrative analysis } \\
\text { Retrospective }\end{array}$ & $\begin{array}{l}\text { The present study aims to understand the experience of women } \\
\text { who undergo feticide in Israel. }\end{array}$ \\
\hline $\begin{array}{l}\text { Leichtentritt } \\
\text { and } \\
\text { Weinberg- } \\
\text { Kurnik, } 2016 \\
\mathbf{2 0}\end{array}$ & Israel & 17 men & $\begin{array}{l}\text { Semi- } \\
\text { structured in- } \\
\text { depth } \\
\text { interviews }\end{array}$ & $\begin{array}{l}\text { Qualitative } \\
\text { Hermeneutic } \\
\text { phenomenology } \\
\text { Retrospective }\end{array}$ & $\begin{array}{l}\text { To examine the experience of Israeli fathers whose fetuses } \\
\text { underwent feticide. }\end{array}$ \\
\hline $\begin{array}{l}\text { Leichtentritt } \\
\text { and Mahat- } \\
\text { Shamir, } \\
2017 \\
\mathbf{2 1}\end{array}$ & Israel & 28 women & $\begin{array}{l}\text { In-depth } \\
\text { interviews }\end{array}$ & $\begin{array}{l}\text { Qualitative } \\
\text { Hermeneutic } \\
\text { methodology } \\
\text { Retrospective }\end{array}$ & $\begin{array}{l}\text { The goal of this research was to reach an interpretive } \\
\text { understanding of the continuing bond experience among Israeli } \\
\text { mothers who underwent feticide, examining the strategies they } \\
\text { use in maintaining a post death relationship with a child they did } \\
\text { not know, whose death they chose and witnessed, within a social } \\
\text { context that ignores their loss and forces them to silence their } \\
\text { grief. }\end{array}$ \\
\hline $\begin{array}{l}\text { Lotto et al., } \\
2016 \\
22\end{array}$ & UK & $\begin{array}{l}10 \text { women } \\
8 \text { men }\end{array}$ & $\begin{array}{l}\text { Semi- } \\
\text { structured } \\
\text { interviews }\end{array}$ & $\begin{array}{l}\text { Qualitative } \\
\text { Constant } \\
\text { comparative- } \\
\text { based approach } \\
\text { Retrospective }\end{array}$ & $\begin{array}{l}\text { To understand the experiences of women and their partners } \\
\text { following the decision to terminate a pregnancy affected by a } \\
\text { severe congenital anomaly. }\end{array}$ \\
\hline $\begin{array}{l}\text { Mitchell, } \\
2016 \\
23\end{array}$ & Canada & 19 women & Interviews & $\begin{array}{l}\text { Qualitative } \\
\text { Retrospective }\end{array}$ & $\begin{array}{l}\text { To explore what are women's responses to the opportunity to see } \\
\text { their fetal bodies. }\end{array}$ \\
\hline $\begin{array}{l}\text { Obst et al., } \\
2021 \\
24\end{array}$ & Australia & 10 men & $\begin{array}{l}\text { Semi- } \\
\text { structured } \\
\text { interviews }\end{array}$ & $\begin{array}{l}\text { Qualitative } \\
\text { Thematic analysis } \\
\text { Retrospective }\end{array}$ & $\begin{array}{l}\text { This study aimed to explore men's experiences of grief and } \\
\text { support following TOPFA including how healthcare providers, } \\
\text { systems and policies can best support men and their families. }\end{array}$ \\
\hline
\end{tabular}

Page 6/21 


\begin{tabular}{|c|c|c|c|c|c|}
\hline Study & Country & Participants & $\begin{array}{l}\text { Data } \\
\text { Collection }\end{array}$ & Methodology & Study Aim \\
\hline $\begin{array}{l}\text { Pitt et al., } \\
2016 \\
25\end{array}$ & Australia & 59 women & $\begin{array}{l}\text { In-depth } \\
\text { interviews }\end{array}$ & $\begin{array}{l}\text { Qualitative } \\
\text { Thematic analysis } \\
\text { Retrospective }\end{array}$ & $\begin{array}{l}\text { Our aim in reporting on women's embodied experiences is to add } \\
\text { detail and depth to health-care professionals' understanding of the } \\
\text { experience of diagnosis and TFA, and to suggest } \\
\text { recommendations as to how care provided to women who } \\
\text { undergo TFA could be enhanced. }\end{array}$ \\
\hline $\begin{array}{l}\text { Qin et al., } \\
2019 \\
26\end{array}$ & China & 41 women & $\begin{array}{l}\text { In-depth } \\
\text { interviews }\end{array}$ & $\begin{array}{l}\text { Qualitative } \\
\text { Grounded theory } \\
\text { Prospective }\end{array}$ & $\begin{array}{l}\text { To understand the cognition, emotions, and behaviour of women } \\
\text { who had recently undergone termination due to a foetal anomaly. } \\
\text { In this study, we developed and tested a theoretical model to } \\
\text { describe how women went through the process after termination. }\end{array}$ \\
\hline $\begin{array}{l}\text { Ramdaney } \\
\text { et al., } 2015 \\
27\end{array}$ & USA & 51 women & Survey & $\begin{array}{l}\text { Quantitative } \\
\text { Prospective }\end{array}$ & $\begin{array}{l}\text { Our study aim was to identify what support, if any, women desire } \\
\text { following a termination of pregnancy for a fetal anomaly. Our } \\
\text { study also investigated if the initial desire for support represented } \\
\text { what women felt they needed in the weeks and months following } \\
\text { the procedure. }\end{array}$ \\
\hline $\begin{array}{l}\text { Smith et al., } \\
2020 \text { a } \\
\mathbf{2 8}\end{array}$ & USA & 124 women & Online survey & $\begin{array}{l}\text { Mixed-Methods } \\
\text { Quantitative - } \\
\text { both surveys were } \\
\text { scored using } \\
\text { respective } \\
\text { analysis tools. } \\
\text { Qualitative - } \\
\text { inductive content } \\
\text { analysis } \\
\text { Retrospective }\end{array}$ & $\begin{array}{l}\text { This study aimed to assess whether there is a significant } \\
\text { difference in ability to cope post-procedure between women who } \\
\text { see a genetic counselor and women who do not see a genetic } \\
\text { counsellor prior to their termination for fetal anomaly. } \\
\text { Additionally, we explored factors that lead women to accept or } \\
\text { decline genetic counselling prior to a termination for fetal anomaly } \\
\text { and expectations for future genetic counselling appointments. }\end{array}$ \\
\hline $\begin{array}{l}\text { Sun et al., } \\
2018 \\
29\end{array}$ & Taiwan & 20 fathers & $\begin{array}{l}\text { Semi- } \\
\text { structured in- } \\
\text { depth } \\
\text { interviews }\end{array}$ & $\begin{array}{l}\text { Qualitative } \\
\text { Descriptive } \\
\text { phenomenological } \\
\text { approach } \\
\text { Retrospective }\end{array}$ & $\begin{array}{l}\text { The aims of this study were to explore and reveal the essence and } \\
\text { structure of the experiences of Taiwanese fathers whose spouses } \\
\text { are hospitalized for pregnancy termination due to fetal } \\
\text { chromosome abnormality. }\end{array}$ \\
\hline $\begin{array}{l}\text { Zareba et al., } \\
2018 \\
\mathbf{3 0}\end{array}$ & Poland & 150 women & Survey & $\begin{array}{l}\text { Quantitative } \\
\text { Retrospective }\end{array}$ & $\begin{array}{l}\text { The aim of the paper is to determine the patients' needs with } \\
\text { regard to support provided by medical personnel and the } \\
\text { healthcare system as well as to establish what forms of support } \\
\text { the patients expect from their partner, family and people in their } \\
\text { surroundings to experience their period of grief in the least } \\
\text { traumatic way. }\end{array}$ \\
\hline
\end{tabular}

Next, empirical findings were imported to NVivo Version 12 for Windows (QSR International, 2018). The findings were then thematically synthesized (Thomas and Harden, 2008) allowing for the analysis of both qualitative and quantitative data as well as providing a transparent and logical framework to explore the experiences and perspectives within a healthcare context (Gamondi et al., 2019). This inductive approach comprised of three stages: 1) line-by-line coding; 2) organisation of codes into descriptive themes; and 3) development of analytical themes (Bazeley, 2009; Sandelowski, 2004). To foster rigour of the coding process, ÁA independently coded a randomly selected 10\% of the included records (Bettany-Saltikov and McSherry, 2016). This was followed by regular discussions amongst authors to examine emerging codes, connections, meanings and themes. Consensus between the reviewers remained high throughout the process.

\section{Results}

A total of 33,261 records were identified through the six databases used in this review. A further 12 records were found as a result of the additional searches. A PRISMA flowchart (Figure 1) presents an overview of the identification and screening process of included studies. 5,523 duplicates were removed, the title and abstract of the remaining 27,738 records were screened and 179 records were assessed as eligible for full text screening. Due to this high volume of studies yielded from the original search (March 2020), the research team agreed to enhance the initial exclusion criteria to ensure a manageable review. The deviations from the original protocol are detailed in Table 3 and an updated search was carried out in August 2021 following the same process using the enhanced exclusion criteria. The updated search in August 2021 followed the same process using the enhanced exclusion criteria (Table 3 ). With the amended criteria, 89 records were excluded. The full text of 90 records were screened, 60 of which were excluded. A total of 30 records ( 26 identified from the original search (March 2020) and 4 from the updated search (August 2021)) were selected for inclusion in this review and were agreed upon by all authors. 
Original Protocol

No exclusion of type of study

Studies that involve health professionals' needs and experiences will be included

Records published between 2000-current will be included

\section{Deviation}

Exclusion criteria - Non-empirical research, case reports, opinion pieces, conference abstracts, editorials

Exclusion criteria - Studies that involve health professionals' needs and experiences

Inclusion criteria - records published between 2010-current

\section{Overview Of Included Studies}

Of the thirty records, twenty-four were qualitative, five quantitative and one mixed-methods (Asplin et al., 2014; Atienza-Carrasco et al., 2020; Carlsson et al., 2016; Chaloumsuk, 2013; Cowchock et al., 2011; Dekkers et al., 2019; Desrochers, 2011; Fisher and Lafarge, 2015; Fisher et al., 2015; Gawron et al., 2013; Hassan, 2015; Irani et al., 2019; Kamranpour et al., 2020a; 2021 Kecir et al., 2021; Koponen et al., 2013; Lafarge et al., 2013; Lafarge et al., 2019; Leichtentritt, 2011; Leichtentritt and Weinberg-Kurnik, 2016; Leichtentritt and Mahat-Shamir, 2017; Lotto et al., 2016; Mitchell, 2016; Obst et al., 2020; Pitt et al., 2016; Qin et al., 2019; Ramdaney et al., 2015; Smith et al., 2020a; Sun et al., 2018; Zareba et al., 2018). The findings presented are based on twenty-eight studies as findings from two studies are reported in four records (Fisher and Lafarge, 2015 and Fisher et al., 2015; and Kamranpour et al., 2020a; 2021). The records were published between 2010 and 2021, with the majority (22) published in 2015 or after (see Figure 2). Sample size of included studies ranged from 7 - 361 participants, with an average of 48 participants per study. Eighteen studies included women only, five involved men only and five included both women and men. Collectively, this review is based on a total sample size of 1,227 women and 114 men.

Study characteristics are summarised in Table 2. The geographical spread of the studies includes, United States of America (USA) (5), UK (4), Israel (3), Iran (2), Sweden (2), Australia (2), and one each from Spain, Thailand, The Netherlands, France, Finland, Canada, China, Taiwan and Poland. One study includes participants from USA and Canada (Hassan, 2015). Twenty-six of the studies are retrospective designs and two prospective (Qin et al., 2019; Ramdaney et al., 2015).

\section{Quality Appraisal Of Included Studies}

Using MMAT Version 2018 (Hong et al., 2018) study quality overall was acceptable. Due to the paucity of research and wide scope of this review no records were excluded on the basis of quality. Two studies did not state whether ethical approval had been sought or obtained (Desrochers, 2011; Koponen et al., 2013), however, the majority of ( 29 out of 30 ) records reported on their adherence to appropriate ethical standards. Two studies acknowledged potential conflicts of interest (Fisher et al., 2015; Lafarge et al., 2013), both relating to the author being involved with the charity that was used as a gatekeeper for recruitment. Two US studies reported offering participants a financial incentive for taking part (Desrochers, 2011; Gawron et al., 2013).

\section{Thematic Synthesis Findings}

Five overarching themes emerged from the synthesis of findings: (1) Context of Care, (2) Person-centred Care, (3) Compassionate Care, (4) Co-ordinated Care, and (5) Inclusive Care. Table 4 summarises the themes and subthemes identified as part of this narrative synthesis. For ease of reading, throughout the findings section, references to the reviewed studies are made using numbers as displayed in Table 2 . 


\begin{tabular}{|c|c|}
\hline Theme & Subtheme \\
\hline Context of Care & Political-legal context \\
\hline \multirow[t]{2}{*}{ The perceived impact and importance of broader contextual factors in parents' access to and experience of care } & Socio-cultural context \\
\hline & Financial implications \\
\hline Person-Centred Care & Information \\
\hline \multirow[t]{2}{*}{ The perceived impact of responsive and respectful healthcare in helping parents feel empowered through this experience } & Choice \\
\hline & Decision Making \\
\hline Compassionate Care & Empathy \\
\hline \multirow{2}{*}{$\begin{array}{l}\text { The perceived quality of the relationship a healthcare professional makes with parents and the impact on their satisfaction with } \\
\text { their care experience }\end{array}$} & Experienced Staff \\
\hline & Non-judgemental Staff \\
\hline Co-ordinated Care & Internal Organisation \\
\hline \multirow[t]{2}{*}{$\begin{array}{l}\text { The perceived impact of the administrative arrangements, service availability and physical environment on the perceived } \\
\text { quality of the care experience }\end{array}$} & $\begin{array}{l}\text { Care Provision and } \\
\text { Pathway }\end{array}$ \\
\hline & Environment \\
\hline Inclusive Care & Invisible Parent \\
\hline $\begin{array}{l}\text { The perceived impact of the health system and healthcare professionals in recognising and facilitating the involvement of } \\
\text { partners }\end{array}$ & Supporting Carers \\
\hline
\end{tabular}

\section{Context of Care}

Political, legal and cultural contexts are pertinent to both the healthcare system and experience of parents undergoing a TOPFA and can shape and impact healthcare service provision, directly and indirectly, including how it is accessed and experienced. Despite TOPFA being legal in 113 countries (Remez et al., 2020), 15 countries of which are represented in this review, there is evidence from the studies that parents' experiences of TOPFA were impacted negatively by wider contextual factors including legislation, local procedures, professional practices and societal attitudes about TOP $(10,12,13,17,21,24,30)$.

Challenges associated with legislation and policy included access to and availability of healthcare. These impacted on parents in a variety of ways, from having to travel or self-fund to access a TOPFA, to experiencing delays because of administrative 'red-tape' which led to delays in decision-making and referrals for the termination, leaving parents anxious about whether the outcome would support their choice or not $(10,19,20,21,24)$.

Funding of the TOP was a pertinent issue for participants from studies in the USA where private medical insurance added a layer of complexity and debate over whether the procedure was 'elective' or 'medical' with the answer determining whether funding would be provided or not (10). This led to women taking action into their own hands with one woman, while awaiting insurance approval searching ways to 'self-abort', and another self-funding the procedure (10). An Iranian study (13) also reported on the financial issues experienced by parents, with some not able to access advanced screening or diagnostic tests and services such as genetic and psychological counselling due to high costs.

\section{Person-centred Care}

Most records (26 out of 30) addressed parents' need for information and the impact it had on their experience $(1-20,22,24,26,28,29,30)$. While most parents acquired information themselves from a range of sources, such as, "healthcare professionals, books, the Internet and from individuals who have been in similar situations" (11), clear and unbiased information provided by healthcare professionals was greatly valued. When parents were given relevant and timely information, particularly about the diagnosed anomaly and healthcare procedures $(1-6,8,9,11,12,14,17,18,19,22,24,26,28,29,30)$, it had a positive impact by reducing their fears and worries, helping them understand their choices, feeling more empowered $(1-4,8,10,11,12,16,17,19,22,24,29,30)$. Parents who felt ill-informed at any stage in the process felt less well-prepared physically and psychologically about what to expect and, for some, their experience was more traumatic $(1-4,8,9,10,11,13,14,16,19,20,22,29)$.

Some studies reported parents' frustration at trying to find information, while others expressed frustration about inconsistent and conflicting information (1, 2 , $8,10,11,16,19)$, "every time I phoned asking this very same question, I received different answers. Very exhausting" (1). This also resulted in dissatisfaction and suspicion about the quality of any information provided, with some feeling that medical staff were withholding information, "we deserved to know what they knew" (10). Being given inappropriate information was distressing, "[it was unhelpful] being handed a leaflet about dealing with a miscarriage almost immediately afterwards when I was clearly dealing with an awful decision which was NOT a miscarriage" (8).

Several studies reported how parents rated the way information was communicated to them $(1-5,8,11,16,17,18,19,21,22,24,28)$. Parents generally felt that written information without the opportunity to discuss it and ask questions was not helpful, "they just gave me a piece of paper [a brochure], but that's not the same as actually talking it through with someone in person" (16). There was no consensus about the use of language by healthcare providers, with some 
parents critical of the use of medicalised terminology $(2,8,11,16,19,21)$, for example, referring to the baby as a "product of conception" ( 8 ) while others were critical of those who referred, "to the fetus as a baby" (8).

For many study participants the point of diagnosis was pivotal, marking the beginning of a different journey where decisions about the future of the pregnancy had to be made $(2,3,4,7,10,11,12,15,18,24,25,26)$ and was emotional and stressful $(2,3,4,7,8,11,12,15,16,18,19,26,27)$. Overall, being given choices was seen as positive and empowering, not just the choice to end the pregnancy but other choices throughout the process $(1,2,6,7,8,9,10,11$, $16,18,19,24,26,27)$, but making the choices was also difficult involving conflicting feelings. Pain relief, for example, was identified as an important choice by some, both the choice to have it and the choice of what pain relief medication they had $(1,2,3,16,17,19,22)$. Being overwhelmed by the choices and decisions to be made was reported in several studies $(2,3,4,6,7,8,9,11,14,18,26,29)$. A study which focused entirely on whether women were given a choice of method of TOPFA (9) found that only $14 \%$ of the sample were, with this number falling to $8 \%$ after 14 weeks gestation.

\section{Compassionate Care}

Healthcare providers' capacity to provide compassionate and empathetic care presented as potentially the most influential element in how parents perceived their experience, positively and negatively. It was explored in 21 out of the 30 records $(1-8,11,12,13,15,16,17,18,19,21,22,24,28,30)$. Women were most satisfied with providers when they responded to their communication and emotional needs $(1-6,8,11,12,16,17,18,19,21,22,28,30)$, as highlighted in a UK study, "The consultant also held my hand tight ... this warmth from the staff I will always remember" (17). A perceived lack of empathy and kindness had lasting impact after the experience, as highlighted by a study in Canada and USA, "the supervisor nurse was kind of brusque and not very friendly and I unfortunately remember that quite clearly" (11).

Healthcare professionals who were perceived to be non-judgmental and who showed kindness and support for parents was greatly valued, "one of the kindest people during the whole process was the anaesthesiologist who held my hand ....and said he understood I was making the right choice" (11). The importance of non-judgmental staff was highlighted as a recurring theme linked to stigma, which was reported in eleven studies $(2,7,8,10,11,12,18,19,22,24,30)$. Parents used words such as 'shame' and 'guilt' to describe how they felt, and perceived judgement or stigmatisation from healthcare professionals was experienced negatively, "I felt she [midwife] made me feel unworthy for my decision" (8).

Parents appreciated practitioners who cared for their baby with tenderness $(8,11,16,17,18,22,23,24,29)$, "the care and attention the midwife on duty showed to our son, ... talking to him as she washed and dressed him" (8) and were distressed when this was not the case. While some parents were ambivalent about spending time with their baby, most positive experiences were reported by those parents who were encouraged and helped to create memories as well as being given as much time as they wanted with their baby $(2,3,4,6,11,15,16,17,18,21,22,23,24,29)$. The facilitation of this by health practitioners was appreciated by parents, "we were allowed to look at him in peace. He was only taken away when we were ready"(16).

Parents valued being cared for by experienced members of staff $(1,4,6,8,10,11,13,15,16,22,26)$ and found it reassuring, "I felt I was being treated by experts" (8). Conversely, being cared for by junior or inexperienced members of staff was found to be distressing and impacted on how confident and safe parents felt by their care, "normal midwives seemed not to know what to do. One told me that she had never delivered a stillborn baby. This was the last thing I needed to hear" (8).

\section{Co-ordinated Care}

Well organised care, which is timely, efficient, and properly resourced was identified as a major contributor in parent satisfaction and was addressed in 18 of the 30 included records $(1,2,4,5,8,9,10,11,13,15,18,19,21,22,24,25,27,29)$. Delays in appointments for further diagnostic tests and slow turnaround times for results were experienced as frustrating and increased parents' anxiety $(2,8,9,10,11,18,19,24,30)$. Any delay post diagnosis was significant and, in some cases, seemed to impact on the choices available due to the gestational age of the fetus $(8,9,10,11,18,19)$. One UK study reported, "increasing pressures around 13-14 weeks' gestation, after which surgical terminations are harder to access in the NHS" (8). Any obstacle or delay once the decision to have a TOPFA had been made increased parent's stress with one participant comparing the wait for the procedure as, "being on death row" (8).

Positive experiences of the healthcare system were reported in terms of the capacity and flexibility of the system and the willingness of staff to be responsive to the particular circumstances of parents $(1,4,8,15)$. This included fast-tracking people for basic procedures, such blood samples, so they did not have any additional waiting $(8,25)$. There was also appreciation when staff ensured women spent little time in open public waiting areas or escorted them quickly and discreetly to a private space $(4,8,11,22)$. Satisfaction was also expressed when staff helped make others aware of their loss to avoid inappropriate comments or questions by staff, "they put a white flower on my door to let them (the staff) know that I was not leaving with a baby" (11).

Co-ordination and continuity of care were also highlighted as important elements of effective care $(1,2,4,5,8,9,10,11,13,18,19,21,22,25,29,30)$. In some instances, the handover of a woman's medical history, notes and ongoing care between practitioners were inadequate, meaning those taking over the care were ill-informed, resulting in poor communication $(1,2,4,8,17)$. Failure to read case notes before seeing a patient led to upsetting experiences for some parents, "I had to tell her the baby had died. She hadn't read the notes properly! I was furious and very distressed" (17). For some, seeing a different doctor every time they attended the clinic impacted on their confidence and resulted in them withholding their fears and concerns (2). A call for continuity of care was specifically reported in four studies $(1,2,8,22)$.

In terms of setting, TOPFAs were carried out in hospital, clinic settings and in abortion clinics. Ten records explored the significance to parents about being cared for in an appropriate environment $(2,4,8,11,13,19,22,23,25,29)$. Negative experiences included, being surrounded by women with healthy 
pregnancies, being close to new mothers and crying newborns, physical indicators of celebration for a newborn, posters on walls of healthy newborns, waiting with women getting an early abortion for an unwanted pregnancy, or waiting with women going for a caesarean section.

There was no consensus about parents' preferences on the most appropriate environment. For those at an earlier gestation, gynaecological wards were preferred by some who wished to avoid being in close proximity to newborns (8) and found the experience of being cared for in settings where other people were giving birth uncomfortable $(2,4,11,22,25,29)$. For others being in a delivery unit validated them as "a pregnant mum" (8) and the gynaecological ward felt inappropriate as it didn't acknowledge their pregnancy was wanted and being separated from 'normal birth' compounded their sense of isolation (8, 22).

Aftercare was identified by some parents as a gap in the services available to them within the healthcare system, and for many was not routinely provided (1, $2,3,6,7,8,11,13,14,16,17,20,24,27,28)$. In the absence of aftercare being provided women expected and wanted healthcare practitioners to signpost them to support organisations $(1,2,6,7,8,11,16,17,22,25,27,28)$. However, it was reported that this often did not happen, and they had to assume personal responsibility to find, and in some cases privately fund aftercare $(1,2,3,6,7,8,11,16,17,22)$. For those who were signposted to or who accessed aftercare, they found it to be helpful and beneficial $(1,2,3,4,5,7,8,10,11,17,21,26)$, "the care was very good. [The] bereavement midwife [was] excellent and I saw her lots after" (8). Parents expressed the view that the aftercare for those who had undergone TOPFA should be bespoke as it was not the same as other perinatal losses and support groups for other infant losses were mostly considered to be unhelpful or inappropriate $(1,2,8,11,17,22,24)$. Preparation, information, and support before a potential future pregnancy was also raised as a concern and need for parents in two studies (14, 28).

\section{Inclusive Care}

Several studies reported that many partners felt excluded or ignored by healthcare staff, and highlighted how the healthcare system in general, and organisational issues in particular, were not designed to cater for them or enable them to support the pregnant woman $(7,13,15,20,22,24,29)$, "it's a no man's land" (20). Partners often felt excluded, ill-prepared and unwelcome, with a partner in one study stating, "it does feel a bit like they forget the father sometimes you know. It was like the bed in the hospital and there was no bed for me. You know, not even a blanket, and [the midwife] said there wasn't enough pillows [for me to have one]" (22). Some rationalised their exclusion because, "pregnancy is a woman's issue" (20). Additional to the hospital environment, fathers also reported a lack of specific aftercare and support targeted towards men, resulting in them feeling uncertain and conflicted between their roles as grieving father and supporting their partner (24).

In some studies, partners identified themselves as the main or only support for their pregnant partner $(6,7,15,20,24,29)$. Women also recognised the central support role their partners played $(2,4,10,17,22,30)$. While partners wanted to care and support their pregnant partner throughout the process, this was more difficult for some when there was, "little professional assistance, empathy or caring" (20). One woman reported, "my husband actually delivered the baby 'cause there was nobody there" (22). In another case, the partner reported, "she was bleeding ... and they [professionals] did nothing! I felt abandoned.... I took care of her" (20). Partners, in these circumstances, felt, "forced to take the situation in your own hands" (20). When professionals supported women and their partners, the experiences of partners were much more positive, "all the people who assisted us [...] were very competent and very nice and that greatly helped" (15).

\section{Discussion}

This systematic review synthesises findings from the international literature on the healthcare experiences and needs of parents who undergo a termination of pregnancy following an antenatal diagnosis of a fetal anomaly. While others have reviewed the evidence concerning this phenomenon from other timeframes and perspectives (Deas, 2017; Lafarge et al., 2014; Jones et al., 2017; Statham et al., 2000; Statham, 2002; Steinberg, 2011; Sullivan and De Faoite, 2017; Wool, 2011), to our knowledge, this is the first review exploring the holistic TOPFA healthcare experience, from diagnosis to aftercare from both parents perspectives. Using the process of thematic analysis this review enhances the knowledge and understanding of the TOPFA healthcare experience and needs of parents and identifies factors that may impact positively and negatively.

Five over-arching themes containing 14 sub-themes (Table 4), generated from 30 records (28 studies), were interpreted in the thematic synthesis. Findings suggested that a trusting relationship with healthcare professionals who provide compassionate care positively impacts on parents' experience of TOPFA. This review also identifies key components that may optimise healthcare practice and enhance quality of care, as well as implications for policy, providing opportunity to improve healthcare provision, organisation and delivery.

\section{Trusting and Compassionate Relationships}

For individuals, their experiences of TOPFA were influenced most by the attitudes, communication style and small acts of kindness shown by healthcare professionals, rather than by their clinical competence. Individual's experiences were more positive, and they felt supported and cared for when staff showed empathy and kindness, listened, took time to explain things, provided relevant information and showed thoughtfulness and compassion by their actions. The converse was true for those who felt they were treated coldly or dismissively, who felt judged or abandoned and were treated by staff who were paternalistic in their approach. While these findings are not dissimilar to the experiences of every pregnant woman (Eds. Byrom and Downe, 2015), the circumstances and the outcome of a TOPFA makes this different (Depoers-Beal et al., 2019; Coleman, 2015; Kamranpour 2020b). Women and their partners want and need staff to connect with them as grieving parents and to acknowledge and respond to the loss of their baby (Davies et al., 2005; Kersting and Wagner, 2012; Smith et al., 2020b).

Effective communication skills are essential for all healthcare staff to navigate the complex interactions involved in supporting parents through TOPFA (Ahmed, 2020; Lafarge et al., 2017; Leonard, 2017). The findings highlight that what and how professionals communicate impacts on how intended and unintended messages can be perceived or interpreted and whether parents feel judged or supported. Effective communication and its role in delivering quality

Page 11/21 
care is already recognised by its inclusion in health professional training (Chan et al., 2020; Slade et al., 2015). However, the findings suggest that a regular focus on communication skills throughout practitioners' careers would be beneficial and could support a better quality service. Examples of how this could be achieved include, through patient feedback, staff appraisal, refresher training or revalidation.

Encouraging and helping individuals to take more responsibility for their health and wellbeing and to have a greater say and choice about the care they receive (Morley and Floridi, 2020; Petrakaki et al., 2018) is in keeping with the shift from a paternalistic model of care to an inclusive and empowering person-centred model (Armstrong, 2014; WHO, 2015) where care is responsive and individualised to a persons' needs (Byrne et al., 2020; Department of Health, 2014). The provision of timely and relevant information by staff is one practical step that would help empower parents to understand what choices they have and give them a greater sense of autonomy in a situation over which they feel they have little control (El-Haddad et al., 2020; Zolkefli, 2017). A sustained focus on developing healthcare staff's understanding of and skills in providing compassionate, person-centred care that supports choice and autonomy of patients throughout their careers could empower staff to improve the experiences not only of parents in these particular circumstances, but of all parents using maternity services (NHS, 2016).

Research in pediatric and neonatal bereavement has seen an increasing focus on meeting the needs of the father following the loss of a child (Aschenbrenner et al., 2012; Leemann et al., 2020; Macdonald et al., 2010; Melin-Johansson et al., 2014). The findings in this review suggest that, with a few exceptions, partners had a negative experience and felt excluded and ignored and need more support both as a grieving parent and in their role as carer to the pregnant woman. Family members have always played an important role as informal carers, particularly in the care of older people or those with disabilities, complementing formal healthcare provision (HM Government, 2019; NICE, 2021) and there is a growing recognition in healthcare policies and laws about the role of carers and their need for support (Carers Trust, 2021, Carers UK, 2019). Awareness raising and training about the need to be inclusive of a woman's primary support (with her permission), and the partner's needs for support both as a grieving parent and as a carer could enhance their experience in the future (Nazaré et al., 2014; Robson, 2002; Sun et al., 2020).

Over recent years there has been an increasing focus on baby loss in maternity care and a recognition of the need for specialist bereavement midwives and services (Abramson, 2019; All-Party Parliamentary Group on Baby Loss, 2016; Helps et al., 2020). This development has the potential to benefit all parents who lose a baby whatever the circumstances, including TOPFA. While lack of experience in dealing with loss is one possible reason why some healthcare staff do not show compassion or empathy to parents experiencing TOPFA, there are a number of other possible reasons why this might be the case. These include lack of knowledge about TOPFA, wanting to remain clinically detached, self-preservation/burnout or, in the respect of TOPFA, disapproval or non-acceptance of termination of pregnancy as an intervention. Exploring the views and feelings of healthcare professionals working in this area of practice would increase an understanding of their needs for support and development as well as consideration of whether there should be specialist and/or designated staff assigned to work with women in these circumstances.

\section{Practice Implications}

Practice refers to the organisation, delivery and administration of care and includes policies, care pathways, clinical guidelines, workforce, caseloads and professional training and how cumulatively these affect the practice within a setting and people's experiences of care. Co-ordination, continuity of care, training, physical setting and aftercare were the common themes identified through this review that impacted positively or negatively on the quality of care and on people's experiences.

For parents who receive a diagnosis of a fetal anomaly, time is critical as a pregnancy has a natural lifespan with a finite time in which decisions can be made. The decision to end the pregnancy and the methods of TOPFA are also time sensitive, particularly when a diagnosis is made at a later gestation and any delays or obstacles following diagnosis can impact on choices available in terms of procedures. Examples in the review of how individual staff facilitated parents through systems in a sensitive and timely manner highlight how practice can be improved. Having a clear care pathway for the management and coordination of the care of parents who receive a diagnosis of fetal anomaly with indicative timelines could also improve practice and the pathway for parents.

Continuity of care could potentially also support better experiences for parents following the diagnosis of a fetal anomaly. A single contact point with whom the parents can build a relationship, discuss their choices, agree their preferred care options and who can then facilitate, organise and advocate for the delivery of that care would be the ideal. The evidence supporting continuity of care is well documented in literature (Hewitt et al., 2021; Homer, 2016; Sandall et al., 2016) and is increasingly seen in government policy and strategies across healthcare disciplines (Hill and Freeman, 2011; NHS, 2017; Sandall, 2018; WHO, 2018).

Healthcare professionals need to be supported and trained to support and meet the needs of parents undergoing TOPFA. The review highlights how people feel more positive when they had confidence in the competence and experience in those caring for them. Where resources permit, experienced or trained staff should provide this service (Leitao et al., 2021). There may be a case for the development of a specialist post but this would need to be based on need which would require accurate and reliable data about prevalence.

The literature review highlighted there was no consensus about the preferred setting for a TOPFA procedure. Where feasible, women should be given the choice of setting. Where it is not feasible and women have to be treated in a maternity ward, this needs to be managed sensitively in ways that minimise further distress for those who have lost a baby.

It appears from the findings that aftercare is not routinely offered following a TOPFA, although many would welcome it. The lack of aftercare can have emotional and physical implications for women's overall health, wellbeing and functioning, including their reproductive health. A care pathway should include aftercare as well as signposting to other services that may be of help to parents in this situation. 
There were examples of good practice and of individuals making exceptions in normal practices to facilitate parents experiencing TOPFA. Gathering, sharing, and showcasing examples of good practice could support and empower staff and teams in other settings to introduce small changes in practice that would improve the quality of care and people's experiences in their care.

\section{Policy Implications}

The findings confirm that the provision of services and care provided by healthcare professionals in respect of TOPFA varies between and within countries for a wide range of legal, socio-economic and cultural reasons. There was, however, one common theme that impacted on individual's experiences that was the stigma and guilt surrounding termination of pregnancy which continues to be a divisive issue within most societies. The attitudes and opinions of people's families and friends, of healthcare professionals, of politicians and of every citizen regarding termination of pregnancy are reflective of those of the wider society with some for, some against and others somewhere in the middle. With limited to no social discourse, TOPFA is shrouded in secrecy and shame (Hanschmidt et al., 2018c), and 'off limits' due to concerns about others' reactions (Traumer et al., 2019). The impact of this results in parents self-silencing, leaving them feeling alone, excluded and marginalized with society creating and maintaining censorship (Chan, 2019; O’Brien, 1993).

In countries where TOPFA is legal, awareness raising, education and information about ethical practice, human rights and conscientious objection could lead to greater understanding and respect for differing viewpoints and help reduce the taboo, stigma and silence surrounding TOP. Anonymised stories of parents who have experienced TOPFA and the experiences of healthcare professionals could also be used to raise awareness of the issues and break the silence.

The stigma and silence can impact on the availability and quality of services, contributing to a 'postcode lottery' of healthcare, which has long been criticised (De Matteis et al., 2019; Graley et al., 2011; McKenzie, 2019). Where TOPFA is legal, clear national policies, guidance about the law, its meaning and intent, as well as the expectations of those providing the service and the rights of those using the service could contribute to a fair system for all. The availability of national clinical guidelines for TOPFA based on evidence and good practice would also provide clarity about what is expected of the service by those using it as well as providing guidance for staff. As with any guidance or care pathway, scope for professional judgement (Schrijvers et al., 2012) would need to be included to allow for a person-centred care approach to meet the specific needs and preferences of each woman and her partner and the unique circumstances of their case.

Additional resources may be required to ensure a quality service for TOPFA. To inform this there needs to be more accurate and reliable data collection to indicate prevalence and need, including the need for specialist medical equipment to improve diagnosis, for training of staff and potentially the need for additional staff to support continuity of care, specialist posts and adequate time to support parents meaningfully through diagnosis, decision-making, treatment and to provide ongoing support and development of new services such as aftercare. There is also a responsibility on governments and healthcare systems to monitor and evaluate how policy and legislation are being implemented and to hold decision-makers and providers to account to provide the expected level of service and comply with the legislation and uphold people's human rights.

\section{Strengths And Limitations}

This systematic literature review and thematic synthesis enhances previous literature, offering another perspective. To our knowledge, it is the first mixedmethods systematic examination and narrative synthesis of the healthcare experiences of both parents of TOPFA. A strength of the review is the utilisation of guidelines and best practice procedures, such as protocol publication to ensure a robust and transparent process. The inductive approach to data analysis, as well as the rigorous and comprehensive search strategy for relevant literature and the evident auditable trail clearly demonstrated the journey from primary studies to interpretations. Independent analysis by two members of the review team enhances credibility.

This review has several limitations. Firstly, it only includes records written in English, possibly omitting significant or insightful studies. There is a small evidence base per country context, and although not the purpose of this review, subsequently means results may not be directly transferrable to dissimilar settings, contexts or samples. There is an over-representation from high-income countries (The World Bank, 2021), drawing attention to possible differences in antenatal care pathways and availability and access of screening and diagnostic services in different countries. Studies in the UK and USA were also overrepresented as well as the majority of participants in studies being from a white ethnic background, middle-class and well educated. This possibility of cultural bias has been noted in other studies exploring this phenomenon (Korenromp et al., 2009; Lafarge et al., 2014; Statham et al., 2001). All studies used convenience, purposive or snowball sampling to recruit participants. While ethically appropriate and justified in relation to the nature of the research, it is important to note that results may not be representative of all parents who experience TOPFA. For a review focusing on both parents' experiences, those of the partner made up less than $10 \%$ of the total sample the findings are based upon, highlighting the dearth of, and need for, more research involving partners in the field of maternity and perinatal care and loss.

\section{Opportunities For Future Research}

In-depth primary research with both parents and health professionals would be beneficial and could help inform and improve service delivery. This knowledge would have the potential to positively impact on parents' experience and improve the quality of care provided. Researching health professionals' experiences would help identify their needs in providing this service. Primary qualitative research exploring other family members experience may also be beneficial as literature alludes to the main support for parents being firstly their respective partner followed by their family network. There is also a need to develop and evaluate interventions with this group aimed at improving their healthcare experience and health outcomes.

\section{Conclusions}


The findings from this review identify the individual nature of people's experiences, needs and responses to the healthcare they received in respect of TOPFA. It has also, importantly, identified a degree of consensus about how compassionate and person-centred care good information and co-ordination can help make parents feel supported and cared for through what is and emotionally traumatic experience.

The skills and attitudes identified are already taught in professional training programmes, although, opportunities to care for parents experiencing TOPFA as part of maternity care are more limited in some settings. Consideration needs to be given to how to ensure expertise and experience can continue to be developed within the workforce to more effectively meet the needs of these parents.

Likewise, a healthcare system that is well-organised and co-ordinated and involves and empowers people in choices and decisions about their care are valued. Improving availability, consistency and quality of services within each jurisdiction should be based on compliance with extant law, human rights, professional leadership, evidence, good practice, sufficient well-trained practitioners and a culture of continuous improvement.

\section{Declarations}

\section{Ethics approval and consent to participate}

Not applicable - Ethical approval was not required for this literature review as no participants, human or animal were involved in the research.

\section{Consent for publication}

Not applicable

\section{Availability of data and materials}

The datasets used and/or analysed during the current study available from the corresponding author on reasonable request.

\section{Competing interests}

The authors declare that they have no competing interests

\section{Funding}

The corresponding author is a PhD Candidate and receives a studentship from the Department for the Economy, Northern Ireland. The views, findings and analysis presented in this paper are those of the authors and are not endorsed by the Department for the Economy.

\section{Authors' contributions}

$\mathrm{SH}$ - Conceptualisation, data collection of literature, analysis, writing and editing

ÁA - Conceptualisation, data collection of literature, analysis, writing and editing

MT - Conceptualisation, analysis, review and editing

\section{Acknowledgements}

We would like to acknowledge the contribution of Nursing and Midwifery subject librarian at Queen's University Belfast, Coleen Tierney, for assistance in refining and evaluating our search criteria.

\section{References}

1. Abramson, P. (2019) Coping with a baby loss as a midwife, British Journal of Midwifery, Volume 27, Issue 2, https://doi.org/10.12968/bjom.2019.27.12.800

2. Adzick, N. S., Thom, E., Spong, C., Brock, J., Burrows, P., Johnson, M., Howell, L., Farrell, J., Dabrowiak, M., Sutton, L., Gupta, N., Tulipan, N., D’Alton, M. and Farmer, D. (2011) A randomized trial of prenatal versus postnatal repair of myelomeningocele, New England Journal of Medicine, Massachussetts Medical Society, 364(11), pp. 993-1004. doi: 10.1056/NEJMoa1014379

3. Ahmed, H. M. (2020) Role of verbal and non-verbal communication of health care providers in general satisfaction with birth care: a cross-sectional study in government health settings of Erbil City, Iraq. Reproductive Health, Volume 17, 35 (2020), https://doi.org/10.1186/s12978-020-0894-3

4. All-Party Parliamentary Group on Baby Loss (2016) Beyond Awareness to Action: Tackling baby loss in the UK, The Lullaby Trust, available from, https://www.lullabytrust.org.uk/wp-content/uploads/APPG-on-baby-loss-Beyond-Awareness-to-Action-Tackling-baby-loss-in-the-UK-1.pdf, (Accessed on 24/08/21)

5. American College of Obstetrics and Gynecologists (2020) Increasing Access to Abortion: Committee Opinion, Number 815, December 2020, available from, https://www.acog.org/clinical/clinical-guidance/committee-opinion/articles/2020/12/increasing-access-to-abortion, (Accessed on: 09/08/21)

6. Armstrong, D. (2014) Actors, patients and agency: a recent history, Sociology of Health and IIIness, Volume 36, Issue 2, pp. 163-174, https://doi.org/10.1111/1467-9566.12100 
7. Aschenbrenner, A.P., Winters, J. M. and Belknap, R. A. (2012) Integrative review: parent perspectives on care of their child at the end of life, Journal of Pediatric Nursing, 2012; 27 (5), pp. 514-522

8. Asplin, N., Wessel, H., Marions, L., and Georgsson Öhman, S. (2014) Pregnancy termination due to fetal anomaly: women's reactions, satisfaction and experiences of care, Midwifery, 30 (6), pp. 620-627. https://doi.org/10.1016/j.midw.2013.10.013

9. Atienza-Carrasco, J., Linares-Abad, M., Padilla-Ruiz, M., \& Morales-Gil, I. M. (2020). Experiences and outcomes following diagnosis of congenital foetal anomaly and medical termination of pregnancy: A phenomenological study. Journal of clinical nursing, 29(7-8), 1220-1237.

https://doi.org/10.1111/jocn.15162

10. Badenhorst, W., Riches, S., Turton, P. and Hughes, P. (2006) The psychological effects of stillbirth and neonatal death on fathers: Systematic review, Journal of Psychosomatic Obstetrics \& Gynecology, 27 (4), pp. 245-256, DOI: https://doi.org/10.1080/01674820600870327

11. Bazeley, P. (2009) Analysing Qualitative Data: More than 'identifying themes', The Malaysian Journal of Qualitative Research, Volume 2, Issue 2, pp. 6-22

12. Berer, M. (2017) Abortion Law and Policy Around the World: In Search of Decriminalization, Health and Human Rights Journal, Volume 19, Number 1, pp. $13-27$

13. Bettany-Saltikov, J. and McSherry, R. (2016) How to do a Systematic Literature Review in Nursing: A step-by-step guide (2 ${ }^{\text {nd }}$ Edition), McGraw-Hill Education, Open University Press, London

14. Boyd, P. A., Devigan, C., Khoshnood, B., Loane, M., Garne, E., Dolk, H., \& EUROCAT Working Group (2008). Survey of prenatal screening policies in Europe for structural malformations and chromosome anomalies, and their impact on detection and termination rates for neural tube defects and Down's syndrome. BJOG : an international journal of obstetrics and gynaecology, 115(6), 689-696. https://doi.org/10.1111/j.1471-0528.2008.01700.x

15. Boyle, B., Addor, M., Arriola, L., et al (2018) Estimating Global Burden of Disease due to congenital anomaly: an analysis of European data, Archives of Disease in Childhood - Fetal and Neonatal Edition 2018;103:F22-F28.

16. Bricker, L., Medley, N., \& Pratt, J. J. (2015). Routine ultrasound in late pregnancy (after 24 weeks' gestation). The Cochrane database of systematic reviews, 2015(6), CD001451. https://doi.org/10.1002/14651858.CD001451.pub4

17. British Pregnancy Advisory Service (2015) Termination of pregnancy for fetal anomaly, available from, https://www.bpas.org/getinvolved/campaigns/briefings/fetal-anomaly/, (Accessed on 08/04/2021)

18. Byrne, A-L., Baldwin, A. and Harvey, C. (2020) Whose centre is it anyway? Defining person-centred care in nursing: An integrative review, PLoS ONE, 15(3): e0229923. https://doi.org/10.1371/journal.pone.0229923

19. Byrom, S. and Downe, S. (Editors) (2015) The Roar Behind The Silence: Why kindness, compassion and respect matter in maternity care, Pinter and Martin Ltd, London

20. Carers Trust (2021) About caring, available from, https://carers.org/about-caring/about-caring, [Accessed on: 22/03/2021]

21. Carers UK (2019) Carers at breaking point: Making the case for carers' breaks in England, Carers UK, London, available from, file:///C:/Users/40048203/Downloads/giveusaabreakaug19final.pdf, [Accessed on 22/03/2021]

22. Carlsson, T., Bergman, G., Karlsson, A. M., Wadensten, B., \& Mattsson, E. (2016). Experiences of termination of pregnancy for a fetal anomaly: A qualitative study of virtual community messages. Midwifery, 41, 54-60. https://doi.org/10.1016/j.midw.2016.08.001

23. Center for Reproductive Rights (2021) The World's Abortion Laws, available from, https://maps.reproductiverights.org/worldabortionlaws, (Accessed on: 09/08/21)

24. Chaloumsuk, N. (2013) Women's experiences of miscarriage and termination of pregnancy for fetal anomaly in Thailand: A phenomenological Study, Doctor of Philosophy Thesis, University of East Anglia, Norwich

25. Chan, S. (2019) Speaking of silence, speaking of art, abortion and Ireland, Irish Studies Review, 27:1, 73-93, D0I: 10.1080/09670882.2018.1560892

26. Chan, K. D., Humphreys, L., Mey, A., Holland, C., Wu, C. and Rogers, G. D. (2020) Beyond communication training: The MaRIS model for developing medical students' human capabilities and personal resilience, Medical Teacher, 42:2, 187-195, DOI: 10.1080/0142159X.2019.1670340

27. Coleman, P. K. (2015) Diagnosis of Fetal Anomaly and the Increased Maternal Psychological Toll Associated with Pregnancy Termination, Issues Law and Medicine, Spring 30 (1), pp. 3-23

28. Covidence systematic review software (2019) Veritas Health Innovation, Melbourne, Australia. Available at www.covidence.org

29. Cowchock, F. S., Meador, K. G., Floyd, S. E., \& Swamy, G. K. (2011). Spiritual needs of couples facing pregnancy termination because of fetal anomalies. The journal of pastoral care \& counseling : JPCC, 65(1-2), 1-10

30. Daum, H., David, A. B., Nadjari, M., Zenvirt, S., Helman, S., Yanai, N., Meiner, V., Yagel, S., Frumkin, A. and Shkedi-Rafid, S. (2019). Role of late amniocentesis in the era of modern genomic technologies, Ultrasound in Obstetrics \& Gynecology, 53, pp. 676-685. https://doi.org/10.1002/uog.20113, 10.1002/uog.20113

31. Davies, V., Gledhill, J., McFadyen, A., Whitlow, B. and Economides, D. (2005) Psychological outcome in women undergoing termination of pregnancy for ultrasound-detected fetal anomaly in the first and second trimesters: A pilot study, Ultrasound in Obstetrics and Gynecology, 25 (2005), pp. $389-392$

32. De Matteis, D., Ishizaka, A. and Resce, G. (2019) The 'postcode lottery' of the Italian public health bill analysed with the hierarchy Stochastic Multiobjective Acceptability Analysis, Socio-Economic Planning Sciences, Volume 68, December 2019, 100603, pp. 1-9, https://doi.org/10.1016/j.seps.2017.12.001

33. Deas, C. (2017) Reducing the psychological impact of terminations for fetal abnormalities: a literature review, Evidence Based Midwifery, 15 (1), pp. $29-34$

34. Dekkers, F., Go, A., Stapersma, L., Eggink, A. J., \& Utens, E. (2019). Termination of pregnancy for fetal anomalies: Parents' preferences for psychosocial care. Prenatal diagnosis, 39(8), 575-587. https://doi.org/10.1002/pd.5464

Page $15 / 21$ 
35. Department of Health (2014) Making Life Better - a whole system framework for public health 2013-2023, available from, https://www.healthni.gov.uk/sites/default/files/publications/dhssps/making-life-better-strategic-framework-2013-2023_0.pdf, (Accessed on: 18/03/2021)

36. Department of Health and Social Care (2020) Abortion Statistics, England and Wales: 2019, https://assets.publishing.service.gov.uk/government/uploads/system/uploads/attachment_data/file/891405/abortion-statistics-commentary-2019.pdf (Accessed on: 03/03/2021)

37. Depoers-Beal, C., Le Baccon, F. A., Le Bouar, G., Proisy, M., Arnaud, A., Legendre, G., Dayan, J., Betremieux, P. and Le Lous, M. (2019) Perinatal grief following neonatal comfort care for lethal fetal condition, Journal of Neonatal-Perinatal Medicine, Volume 12 (4), pp. 457-464, D0I: 10.3233/NPM-180180

38. Desrochers, J. (2011) The Psychosocial Impact of Termination of Pregnancy for Fetal Anomaly on the Male Partner, Masters Thesis, Brandeis University, Boston

39. Due, C., Chiarolli, S. and Riggs, D.W. (2017) The impact of pregnancy loss on men's health and wellbeing: a systematic review, BMC Pregnancy and Childbirth, 17, 380: https://doi.org/10.1186/s12884-017-1560-9

40. El-Haddad, C., Hegazi, I., \& Hu, W. (2020). Understanding Patient Expectations of Health Care: A Qualitative Study. Journal of patient experience, 7(6), 1724-1731. https://doi.org/10.1177/2374373520921692

41. Fisher, J. and Lafarge, C. (2015) Women's experience of care when undergoing termination of pregnancy forfetal anomaly in England, Journal of Reproductive and Infant Psychology, 33(1), pp. 69-87. doi: 10.1080/02646838.2014.970149

42. Fisher, J., Lohr, P. A., Lafarge, C., \& Robson, S. C. (2015). Termination for fetal anomaly: are women in England given a choice of method? Journal of obstetrics and gynaecology : the journal of the Institute of Obstetrics and Gynaecology, 35(2), 168-172. https://doi.org/10.3109/01443615.2014.940291

43. Gamondi, C., Fusi-Schmidhauser, T., Oriani, A., Payne, S., \& Preston, N. (2019). Family members' experiences of assisted dying: A systematic literature review with thematic synthesis. Palliative medicine, 33(8), 1091-1105. https://doi.org/10.1177/0269216319857630

44. Ganesamoorthy, D., Bruno, D. L., McGillivray, G., Norris, F., White, S. M., Adroub, S., Amor, D. J., Yeung, A., Oertel, R., Pertile, M. D., Ngo, A., Arvaj, A. R., Walker, S., Charan, P., Palma-Dias, R., Woodrow, N. and Slater, H. R. (2013) Meeting the challenge of interpreting high-resolution single nucleotide polymorphism array data in prenatal diagnosis: does increased diagnostic power outweigh the dilemma of rare variants? BJOG: An International Journal of Obstetrics \& Gynaecology, 120, Issue 5, pp. 594-606. https://doi.org/10.1111/1471-0528.12150, 10.1111/1471-0528.12150

45. Gawron, L. M., Cameron, K. A., Phisuthikul, A., \& Simon, M. A. (2013). An exploration of women's reasons for termination timing in the setting of fetal abnormalities. Contraception, 88(1), 109-115, https://doi.org/10.1016/j.contraception.2012.12.004

46. Graley, C.E., May, K.F. and McCoy, D.C. (2011) Postcode Lotteries in Public Health - The NHS Health Checks Programme in North West London. BMC Public Health 11, 738 (2011), https://doi.org/10.1186/1471-2458-11-738

47. Guttmacher Institute (2021) State Laws and Policies: Abortion Bans in Cases of Sex or Race Selection or Genetic Anomaly (as on July 1, 2021), available from, https://www.guttmacher.org/state-policy/explore/abortion-bans-cases-sex-or-race-selection-or-genetic-anomaly, (Accessed on: 09/08/21)

48. Hannes, K., Lockwood, C., and Pearson, A. (2010) A comparative analysis of three online appraisal instruments' ability to assess validity in qualitative research, Qualitative Health Research, 20 (12), pp. 1736-1743 https://doi.org/10.1177/1049732310378656

49. Hanschmidt, F., Nagl, M., Klingner, J., Stepan, H., and Kersting, A. (2018a) Abortion after diagnosis of fetal anomaly: Psychometric properties of a German version of the individual level abortion stigma scale, PLOS ONE, 13 (6): e0197986, https://doi.org/10.1371/journal.pone.0197986

50. Hanschmidt, F., Hoffmann, R., Klingner, J., Kersting, A., \& Stepan, H. (2018b). Help-seeking Following Termination of Pregnancy after Diagnosis of Fetal Anomaly: Women's Intentions and Experiences 1 to 7 Years after the Event. Geburtshilfe und Frauenheilkunde, 78(2), 160-166. https://doi.org/10.1055/s0044-100380

51. Hanschmidt, F., Treml, J., Klingner, J., Stepan, H. and Kersting, A. (2018c) Stigma in the context of pregnancy termination after diagnosis of fetal anomaly: associations with grief, trauma, and depression, Archives of Women's Mental Health, 21, pp. 391-399 https://doi.org/10.1007/s00737-017-0807-9

52. Hassan, H. (2015) Women's long-term life experience after pregnancy termination for fetal abnormality: Interpretive phenomenological study, Doctor of Philosophy Thesis, The University of Western Ontario, London, Ontario

53. Health (Regulation of Termination of Pregnancy) Act (2018), available from, https://data.oireachtas.ie/ie/oireachtas/act/2018/31/eng/enacted/a3118.pdf, (Accessed on 08/04/2021)

54. Heaney, S., Aventin, Á. and Tomlinson, M. (2020) Termination of pregnancy for fetal anomaly: a systematic review of the healthcare needs and experiences of parents. PROSPERO 2020, CRD42020175970 Available from: https://www.crd.york.ac.uk/prospero/display_record.php? ID=CRD42020175970

55. Helps, A., O’Donoghue, K., O’Byrne, L., Greene, R. and Leitao, S. (2020) Impact of bereavement care and pregnancy loss services on families: Findings and recommendations from Irish inquiry reports, Midwifery, Volume 91, 102841, https://doi.org/10.1016/j.midw.2020.102841

56. Hewitt, L., Dahlen, H. G., Hartz, D. L. and Dadich, A. (2021) Leadership and management in midwifery-led continuity of care models: A thematic and lexical analysis of a scoping review, Midwifery, Volume 98 (2021), 102986

57. Hill, A. P. and Freeman, G. K. (2011) Promoting Continuity of Care in General Practice (RCGP Policy Paper), The Royal College of General Practitioners, London

58. HM Government (2019) 2019-20 Better Care Fund: Policy Framework, Department of Health and Social Care and the Ministry of Housing, Communities and Local Government, available from,

https://assets.publishing.service.gov.uk/government/uploads/system/uploads/attachment_data/file/821676/Better_Care_Fund_2019-

20_Policy_Framework.pdf, [Accessed on: 22/03/2021] 
59. Homer, C. S. E. (2016) Models of maternity care: evidence for midwifery continuity of care, The Medical Journal of Australia, Volume 205, Issue 8, pp. 370374

60. Hong, Q. N., Pluye, P., Fàbregues, S., Bartlett, G., Boardman, F., Cargo, M., Dagenais, P., Gagnon, M. P., Griffiths, F., Nicolau, B., O'Cathain, A., Rousseau, M. C. and Vedel, I. (2018) Mixed Methods Appraisal Tool (MMAT), Version 2018, Registration of Copyright (\#1148552), Canadian Intellectual Property Office, Industry Canada

61. House of Commons (1990) Human Fertilisation and Embryology Act 1990, HMSO, London

62. Hyatt, E. D. G. (2019) Counseling Women Who Have Terminated a Pregnancy Due to Fetal Anomaly (TOPFA): The ACCEPT Model, Clinical Social Work Journal, November, 1-12, DOI: 10.1007/s10615-019-00732-0

63. Institute of Obstetricians and Gynecologists (2019) Interim Clinical Guidance, PATHWAY FOR MANAGEMENT OF FATAL FETAL ANOMALIES AND/OR LIFE-LIMITING CONDITIONS DIAGNOSED DURING PREGNANCY: TERMINATION OF PREGNANCY, available from, https://rcpi-livecdn.s3.amazonaws.com/wp-content/uploads/2019/01/IOG-TOPFA-PATHWAY-FINAL-180119.pdf, (Accessed on 04/03/2021)

64. Irani, M., Khadivzadeh, T., Asghari Nekah, S. M., Ebrahimipour, H., \& Tara, F. (2019). Emotional and Cognitive Experiences of Pregnant Women Following Prenatal Diagnosis of Fetal Anomalies: A Qualitative Study in Iran. International journal of community based nursing and midwifery, 7(1), 22-31. https://doi.org/10.30476/IJCBNM.2019.40843

65. Jiwani, S. S., Amouzou-Aguirre, A., Carvajal, L., Chou, D., Keita, Y., Moran, A. C., Requejo, J., Yaya, S., Vaz, L. M., \& Boerma, T. (2020). Timing and number of antenatal care contacts in low and middle-income countries: Analysis in the Countdown to 2030 priority countries. Journal of global health, 10(1), 010502. https://doi.org/10.7189/jogh.10.010502

66. Jones, K., Baird, K., \& Fenwick, J. (2017). Women's experiences of labour and birth when having a termination of pregnancy for fetal abnormality in the second trimester of pregnancy: A qualitative meta-synthesis. Midwifery, 50, 42-54. https://doi.org/10.1016/j.midw.2017.03.014

67. Kamranpour, B., Noroozi, M. and Bahrami, M. (2018) The Needs of Women Who Have Experienced Pregnancy Termination Due to Fetal Anomalies: A Literature Review, Iranian Journal of Nursing and Midwifery Research, Volume 24, Issue 1

68. Kamranpour, B., Noroozi, M. and Bahrami, M. (2020a) A qualitative study exploring the needs related to the health system in women with experience of pregnancy termination due to fetal anomalies in Iran, BMC Pregnancy and Childbirth, Volume 20, Issue 573

69. Kamranpour, B., Noroozi, M. and Bahrami, M. (2020b) Psychological experiences of women with pregnancy termination due to fetal anomalies: a qualitative study from the perspective of women, their spouses, and healthcare providers in Iran, Reproductive Health, 17, 109 (2020). https://doi.org/10.1186/s12978-020-00959-y

70. Kamranpour, B., Noroozi, M. and Bahrami, M. (2021) Termination of Pregnancy for Fetal Anomalies: A Qualitative Study of the Informational and Educational Needs of Women, Iranian Journal of Nursing and Midwifery Research, Volume 26, pp. 97-103

71. Kecir, K. A., Rothenburger, S., Morel, O., Albuisson, E. and Ligier, F. (2021) Experiences of fathers having faced with termination of pregnancy for foetal abnormality, Journal of Gynecology Obstetrics and Human Reproduction 2021 Jan; 50 (1):101818. doi: 10.1016/j.jogoh.2020.101818.

72. Kersting, A. and Wagner, B. (2012) Complicated grief after perinatal loss. Dialogues in clinical neuroscience, 14 (2), pp. 187-194 https://doi.org/10.31887/DCNS.2012.14.2/akersting

73. Koponen, K., Laaksonen, K., Vehkakoski, T. and Vehmas, S., 2013. Parental and professional agency in terminations for fetal anomalies: analysis of Finnish women's accounts. Scandinavian Journal of Disability Research, 15(1), pp.33-44. DOI: http://doi.org/10.1080/15017419.2012.660704

74. Korenromp, M. J., Page-Christiaens, G. C. M. L., van den Bout, J,, Mulder, E. J. H. and Visser, G. H. A. (2009) Adjustment to termination of pregnancy for fetal anomaly: a longitudinal study in women at 4, 8, and 16 months, American Journal of Obstetrics and Gynecololgy, 2009;201:160.e1-e7

75. Lafarge, C., Mitchell, K. and Fox, P. (2013) Women's Experiences of Coping With Pregnancy Termination for Fetal Abnormality, Qualitative Health Research, Vol 23, Issue 7, pp. 924-936

76. Lafarge, C., Mitchell, K. and Fox, P. (2014) Termination of pregnancy for fetal abnormality: a meta-ethnography of women's experiences, Reproductive Health Matters, 22:44, pp. 191-201, DOI: 10.1016/S0968-8080(14)44799-2

77. Lafarge, C., Mitchell, K. and Fox, P. (2017) Posttraumatic growth following pregnancy termination for fetal abnormality: the predictive role of coping strategies and perinatal grief, Anxiety, Stress \& Coping, Volume 30, Issue 5, pp. 536-550, DOI: 10.1080/10615806.2016.1278433

78. Lafarge, C., Rosman, S, and Ville, I. (2019) Pregnancy termination for fetal abnormality: ambivalence at the heart of women's experience. Women's Studies International Forum, 74. pp. 42-51. ISSN 0277-5395

79. Leemann, T., Bergstraesser, E., Cignacco, E. and Zimmermann, K. (2020) Differing needs of mothers and fathers during their child's end-of-life care: secondary analysis of the "Paediatric end-of-life care needs" (PELICAN) study, BMC Palliative Care, 19, 118, https://doi.org/10.1186/s12904-020-00621-1

80. Leichtentritt R. D. (2011). Silenced voices: Israeli mothers' experience of feticide. Social science \& medicine (1982), 72(5), 747-754. https://doi.org/10.1016/j.socscimed.2010.12.021

81. Leichtentritt, R. D., \& Weinberg-Kurnik, G. (2016). No one sees the fathers: Israeli fathers' experience of feticide. Social science \& medicine (1982), 168, 159-166. https://doi.org/10.1016/j.socscimed.2016.09.002

82. Leichtentritt, R. D., \& Mahat-Shamir, M. (2017). Mothers' Continuing Bond With the Baby: The Case of Feticide. Qualitative health research, 27(5), 665676. https://doi.org/10.1177/1049732315616626

83. Leitao, S., Helps, A., Cotter, R. and O'Donoghue, K. (on behalf of the TEARDROP PLGR working group) (2021) Development and evaluation of TEARDROP a perinatal bereavement care training programme for healthcare professionals, Midwifery, Volume 98, 102978, pp. 1-6,

https://doi.org/10.1016/j.midw.2021.102978

Page $17 / 21$ 
84. Leonard, P. (2017) Exploring ways to manage healthcare professional-patient communication issues, Support Care Cancer, Volume 25 (Supplement 1), S7S9

85. Lotto, R., Armstrong, N., and Smith, L. K. (2016) Care provision during termination of pregnancy following diagnosis of a severe congenital anomaly - A qualitative study of what is important to parents. Midwifery. 2016 Dec; 43: pp.14-20. DOI: 10.1016/j.midw.2016.10.003.

86. Lozano, R., Naghavi, M., Foreman, K., Lim, S., Shibuya, K., Aboyans, V., Abraham, J., Adair, T., Aggarwal, R., Ahn, S. Y., Alvarado, M., Anderson, H. R., Anderson, L. M., Andrews, K. G., Atkinson, C., Baddour, L. M., Barker-Collo, S., Bartels, D. H., Bell, M. L., Benjamin, E. J., ... Memish, Z. A. (2012) Global and regional mortality from 235 causes of death for 20 age groups in 1990 and 2010: a systematic analysis for the Global Burden of Disease Study 2010. Lancet (London, England), 380(9859), 2095-2128. https://doi.org/10.1016/S0140-6736(12)61728-0

87. Macdonald, M. E., Chilibeck, G., Affleck, W. and Cadell, S. (2010) Gender imbalance in pediatric palliative care research samples, Palliative Medicine, 2010; Volume 24, Issue 4, pp. 435-444

88. Maurice, P., Letourneau, A., Benachi, A. and Jouannic, J. (2019) Feticide in second- and third-trimester termination of pregnancy forfetal anomalies: Results of a national survey, Prenatal Diagnosis, p. pd.5594. doi: 10.1002/pd.5594

89. McCreight, B. S. (2004) A grief ignored: narratives of pregnancy loss from a male perspective, Sociology of Health and IIIness, Volume 26, Issue 3, April, pp. 326-350, https://doi.org/10.1111/j.1467-9566.2004.00393.x

90. McKenzie, R. (2019) Another postcode lottery? 15000 people with complex neurological conditions living in general care homes, Nursing and Residential Care, Volume 21, Issue 10, https://doi.org/10.12968/nrec.2019.21.10.551

91. Melin-Johansson, C., Axelsson, I., Grundberg, M. J. and, Hallqvist, F. (2014) When a child dies: parents' experiences of palliative care-an integrative literature review, Journal of Pediatric Nursing, Volume 29, Issue 6, pp. 660-669

92. Mitchell, L. M. (2016) "Time with Babe”: Seeing Fetal Remains after Pregnancy Termination for Impairment, Medical Anthropology Quarterly, Volume 30, Issue 2, June 2016, pp. 168-185, https://doi.org/10.1111/maq.12173

93. Modell, B., Berry, R. J., Boyle, C. A., Christianson, A., Darlison, M., Dolk, H., Howson, C. P., Mastroiacovo, P., Mossey, P., \& Rankin, J. (2012). Global regional and national causes of child mortality. Lancet (London, England), 380(9853), 1556-1557. https://doi.org/10.1016/S0140-6736(12)61878-9

94. Morley, J. and Floridi, L. (2020) The Limits of Empowerment: How to Reframe the Role of mHealth Tools in the Healthcare Ecosystem, Science and Engineering Ethics, Volume 26, pp. 1159-1183, https://doi.org/10.1007/s11948-019-00115-1

95. Murphy, E., Dingwall, R., Greatbatch, D., Parker, S. and Watson, P. (1998) Qualitative research methods in health technology assessment: a review of the literature. Health Technol Assess, 1998, 2 (16)

96. Myers, J. E. and Seif, M. W. (2010) Global perspective of legal abortion - Trends analysis and accessibility, Best Practice \& Research Clinical Obstetrics \& Gynaecology, Volume 24, Issue 4, August 2010, pp. 457-466

97. Nazaré, B., Fonseca, A. and Canavarro, M. C. (2014) Trauma Following Termination of Pregnancy for Fetal Abnormality: Is This the Path From Guilt to Grief?, Journal of Loss and Trauma, Volume 19, Issue 3, pp. 244-261, DOI: 10.1080/15325024.2012.743335

98. NHS (2016) National Maternity Review, Better Births - Improving outcomes of maternity services in England: A Five Year Forward View of maternity care, available from, https://www.england.nhs.uk/wp-content/uploads/2016/02/national-maternity-review-report.pdf, (Accessed on: 18/03/2021)

99. NHS (2017) Implementing Better Births: Continuity of Carer, available from, https://www.england.nhs.uk/wp-content/uploads/2017/12/implementingbetter-births.pdf, (Accessed on 08/04/2021)

100. NICE (2021) Supporting Adult Carers (Quality Standard QS200), available from, https://www.nice.org.uk/guidance/QS200, [Accessed on: 22/03/2021]

101. Obst, K. L., Due, C., Oxlad, M., \& Middleton, P. (2020). Men's grief following pregnancy loss and neonatal loss: a systematic review and emerging theoretical model. BMC pregnancy and childbirth, 20(1), 11. https://doi.org/10.1186/s12884-019-2677-9

102. Obst, K. L., Due, C., Oxlad, M., \& Middleton, P. (2021) Men's experiences and need for targeted support after termination of pregnancy for foetal anomaly: A qualitative study, Journal of Clinical Nursing, Volume 30, pp. 2718-2731

103. Office for National Statistics (2020) Births in England and Wales: 2019, Stillbirths, available from,

https://www.ons.gov.uk/peoplepopulationandcommunity/birthsdeathsandmarriages/livebirths/bulletins/birthsummarytablesenglandandwales/2019\#stil (Accessed on 04/03/2021)

104. O'Brien J. (1993). Conspiracy of silence. Planned parenthood challenges, (1), 17-19.

105. O'Connell, O., Meaney, S. and O'Donoghue, K. (2016) Caring for parents at the time of stillbirth: How can we do better? Women and Birth, Volume 29, Issue 4, pp. 345-349, https://doi.org/10.1016/j.wombi.2016.01.003

106. O'Leary, J. and Thorwick, C. (2006) Fathers' Perspectives During Pregnancy, Postperinatal Loss, Journal of Obstetric, Gynecologic \& Neonatal Nursing, Volume 35, Issue 1, January-February 2006, pp. 78-86, DOI: https://doi.org/10.1111/j.1552-6909.2006.00017.x

107. Page, M. J., McKenzie, J. E., Bossuyt, P. M., Boutron, I., Hoffman, T. C., Mulrom, C. D. et al (2021) The PRISMA 2020 statement: an updated guideline for reporting systematic reviews, BMJ, 2021, 372: n71, doi: https://doi.org/10.1136/bmj.n71

108. Pan, M., Huang, L. Y., Zhen, L. and Li, D. Z. (2018) A cost-effectiveness analysis comparing two different strategies in advanced maternal age: Combined first-trimester screening and maternal blood cell-free DNA testing, Taiwanese Journal of Obstetrics \& Gynecology, Volume 57, pp. 536-540,

https://doi.org/10.1016/j.tjog.2018.06.011, 10.1016/j.tjog.2018.06.011

109. Petrakaki, D., Hilberg, E. and Waring, J. (2018) Between empowerment and self-discipline: Governing patients' conduct through technological self-care, Social Science \& Medicine, Volume 213, 2018, pp. 146-153, ISSN 0277-9536, https://doi.org/10.1016/j.socscimed.2018.07.043.

110. Pitt, P., McClaren, B. J., and Hodgson, J. (2016). Embodied experiences of prenatal diagnosis of fetal abnormality and pregnancy termination. Reproductive health matters, 24(47), 168-177. https://doi.org/10.1016/j.rhm.2016.04.003

Page $18 / 21$ 
111. Pluye, P., Gagnon, M. P., Griffiths, F. and Johnson-Lafleur, J. (2009) A scoring system for appraising mixed methods research, and concomitantly appraising qualitative, quantitative and mixed methods primary studies in mixed studies reviews. International Journal of Nursing Studies, Volume 46 , Issue 3, pp. 529-546

112. Public Health England (2013) NHS Fetal Anomaly Screening Programme (FASP): programme overview, Public Health England, available from, https://www.gov.uk/guidance/fetal-anomaly-screening-programme-overview, (Accessed on 04/03/2021)

113. Public Health England (2020) National Congenital Anomaly and Rare Disease Registration Service: Congenital anomaly statistics 2018, Public Health England, London, available from,

https://assets.publishing.service.gov.uk/government/uploads/system/uploads/attachment_data/file/1008030/NCARDRS_Congenital_anomaly_statistics (Accessed on 09/08/21)

114. Qin, C., Chen, W. T., Deng, Y., Li, Y., Mi, C., Sun, L., \& Tang, S. (2019). Cognition, emotion, and behaviour in women undergoing pregnancy termination for foetal anomaly: A grounded theory analysis. Midwifery, 68, 84-90. https://doi.org/10.1016/j.midw.2018.10.006

115. QSR International Pty Ltd. (2018) NVivo (Version 12), https://www.qsrinternational.com/nvivo-qualitative-data-analysis-software/home

116. Raich, A. L., \& Skelly, A. C. (2013). Asking the right question: specifying your study question. Evidence-based spine-care journal, 4(2), 68-71. https://doi.org/10.1055/s-0033-1360454

117. Ramdaney, A., Hashmi, S. S., Monga, M., Carter, R. and Czerwinski, J. (2015) Support Desired by Women Following Termination of Pregnancy for a Fetal Anomaly, Journal of Genetic Counseling, 24 (6), pp. 952-960, DOI: 10.1007/s10897-015-9832-x

118. Remez, L., Mayall, K. and Singh, S. (2020) Global Developments in Laws on Induced Abortion: 2008-2019, International Perspectives on Sexual and Reproductive Health, Volume 46, Supplement 1, Focus on Abortion, pp. 53-65. Published by Guttmacher Institute

119. Robson, F. M. (2002) 'Yes! - A chance to tell my side of the story': A case study of a male partner of a woman undergoing termination of pregnancy for fetal abnormality, Journal of Health Psychology, 7 (2), pp. 183-193

120. Sandall, J. (2018) Measuring Continuity of Carer: A monitoring and evaluation framework, Kings College London and Royal College of Midwives, available from, https://www.rcm.org.uk/media/2465/measuring-continuity-of-carer-a-monitoring-and-evaluation-framework.pdf, (Accessed on, 08/04/2021)

121. Sandall, J., Soltani, H., Gates, S., Shennan, A., \& Devane, D. (2016). Midwife-led continuity models versus other models of care for childbearing women. The Cochrane database of systematic reviews, 4, CD004667. https://doi.org/10.1002/14651858.CD004667.pub5

122. Sandelowski, M. (2004) Using qualitative research, Qualitative Health Research, 14, pp. 1366-1386

123. Schrijvers, G., van Hoorn, A., \& Huiskes, N. (2012). The care pathway: concepts and theories: an introduction. International journal of integrated care, 12 (Spec Ed Integrated Care Pathways), e192. https://doi.org/10.5334/ijic.812

124. Singh, S., Remez, L., Sedgh, G., Kwok, L. and Onda, T. (2017) Abortion Worldwide 2017: Uneven Progress and Unequal Access, Guttmacher Institute, 2017, available from, https://www.guttmacher.org/report/abortion-worldwide-2017\# (Accessed on 27/01/21)

125. Sitkin, N. A., Ozgediz, D., Donkor, P., \& Farmer, D. L. (2015). Congenital anomalies in low- and middle-income countries: the unborn child of global surgery. World journal of surgery, 39(1), 36-40. https://doi.org/10.1007/s00268-014-2714-9

126. Slade, D., Manidis, M., McGregor, J., Scheeres, H., Chandler, E., Stein-Parbury, J., Dunston, R., Herke, M., and Matthiessen, C. (2015) Communicating in hospital emergency departments, Berlin (Germany): Springer-Verlag

127. Smith, L. K., Dicken, J., Atik, R. B., Bevan, C., Fisher, J. and Hinton, L. (2020b) Parents' experiences of care following the loss of a baby at the margins between miscarriage, stillbirth and neonatal death: a UK qualitative study, BJOG An International Journal of Obstetrics and Gynaecology, Volume 127, Issue 7, June, pp. 868-874, https://doi.org/10.1111/1471-0528.16113

128. Smith, C., Hashmi, S. S., Czerwinski, J., Wagner, V. F., Promecene, P., Milentijevic, I. and Ramdaney, A. (2020a) The impact of genetic counseling on women's grief and coping following termination of pregnancy for fetal anomaly, Journal of Genetic Counselors, Volume 30, pp. 522-532

129. Spencer, L., Ritchie, J., Lewis, J. and Dillon, L. (2003) Quality in Qualitative Evaluation: A framework for assessing research evidence, London: Cabinet Office

130. Statham, H., Solomou, W., \& Chitty, L. (2000). Prenatal diagnosis of fetal abnormality: psychological effects on women in low-risk pregnancies. Bailliere's best practice \& research. Clinical obstetrics \& gynaecology, 14(4), 731-747. https://doi.org/10.1053/beog.2000.0108

131. Statham, H., Solomou, W. and Green, J. M. (2001) When a baby has an abnormality: a study of parents' experiences, Centre for Family Research, University of Cambridge: Cambridge

132. Statham, H. (2002) Prenatal diagnosis of fetal abnormality: The decision to terminate the pregnancy and the psychological consequences, Fetal and Maternal Medicine Review, 13 (4), pp. 213-247. doi:10.1017/S09655539502000414

133. Steinberg J. R. (2011). Later abortions and mental health: psychological experiences of women having later abortions-a critical review of research. Women's health issues : official publication of the Jacobs Institute of Women's Health, 21(3 Suppl), S44-S48. https://doi.org/10.1016/j.whi.2011.02.002

134. Sullivan, N. and deFaoite, E. (2017) Psychological Impact of Abortion due to Fetal Anomaly: A Review of Published Research. Issues in Law and Medicine, 32 (1), pp.19-30

135. Sun, J. C., Rei, W., Chang, M. Y., \& Sheu, S. J. (2018). The Experiences of Fathers Whose Spouses Are Hospitalized for Pregnancy Termination Due to Fetal Chromosome Abnormality in Taiwan. The journal of nursing research : JNR, 26(4), 297-305. https://doi.org/10.1097/jnr.0000000000000246

136. Sun, S., Yang, M., Zhang, J., Zhou, X., Jia, G. and Yu, X. (2020) Family support for pregnant women with foetal abnormality requiring pregnancy termination in China, Health and Social Care in the Community, Volume 28, Issue 3, May, pp. 1020-1029, https://doi.org/10.1111/hsc.12935 
137. The World Bank (2021) World Bank Country and Lending Groups, available from, https://datahelpdesk.worldbank.org/knowledgebase/articles/906519world-bank-country-and-lending-groups (Accessed on: 19/01/2021)

138. Thomas, J., \& Harden, A. (2008). Methods for the thematic synthesis of qualitative research in systematic reviews. BMC medical research methodology, 8 , 45. https://doi.org/10.1186/1471-2288-8-45

139. Traumer, L., Jacobsen, M. H., \& Laursen, B. S. (2019). Patients' experiences of sexuality as a taboo subject in the Danish healthcare system: a qualitative interview study. Scandinavian journal of caring sciences, 33(1), 57-66. https://doi.org/10.1111/scs.12600

140. Whitworth, M., Bricker, L., \& Mullan, C. (2015). Ultrasound for fetal assessment in early pregnancy. The Cochrane database of systematic reviews, 2015(7), CD007058. https://doi.org/10.1002/14651858.CD007058.pub3

141. WHO (2015) WHO global strategy on people-centred and integrated health services, available from, https://www.who.int/servicedeliverysafety/areas/people-centred-care/global-strategy/en/, (Accessed on 18/03/2021)

142. WHO (2016) WHO recommendations on antenatal care for a positive pregnancy experience, available from, https://apps.who.int/iris/bitstream/handle/10665/250796/9789241549912-eng.pdf;jsessionid=84EAD9665FADFB01E08E859AF63BCEBE?sequence=1 (Accessed on 03/03/2021)

143. WHO (2018) Continuity and coordination of care, available from, https://apps.who.int/iris/bitstream/handle/10665/274628/9789241514033-eng.pdf? ua=1, (Accessed on 08/04/2021)

144. WHO (2020a) Congenital anomalies, available from, https://www.who.int/news-room/fact-sheets/detail/congenital-anomalies, (Accessed on $08 / 04 / 2021)$

145. WHO (2020b) Newborns: improving survival and well-being, WHO, Geneva, available from, https://www.who.int/news-room/fact-sheets/detail/newbornsreducing-mortality, (Accessed on 04/03/2021)

146. Wool C. (2011). Systematic review of the literature: parental outcomes after diagnosis of fetal anomaly. Advances in neonatal care: official journal of the National Association of Neonatal Nurses, 11(3), 182-192. https://doi.org/10.1097/ANC.0b013e31821bd92d

147. Zaręba, K., Makara-Studzińska, M., Ciebiera, M., Gierus, J., \& Jakiel, G. (2018). Role of Social and Informational Support while Deciding on Pregnancy Termination for Medical Reasons. International journal of environmental research and public health, 15(12), 2854. https://doi.org/10.3390/ijerph15122854

148. Zolkefli Y. (2017). Evaluating the Concept of Choice in Healthcare. The Malaysian journal of medical sciences : MJMS, 24(6), 92-96. https://doi.org/10.21315/mjms2017.24.6.11

149. Zwiers, C., Oepkes, D., Lopriore, E., Klumpber, F., de Haas, M. and van Kamp, I. (2018) The near disappearance of fetal hydrops in relation to current state-ofthe-art management of red cell alloimmunization, Prenatal Diagnosis, John Wiley and Sons Ltd, 38(12), pp. 943-950. doi: 10.1002/pd.5355

\section{Figures}




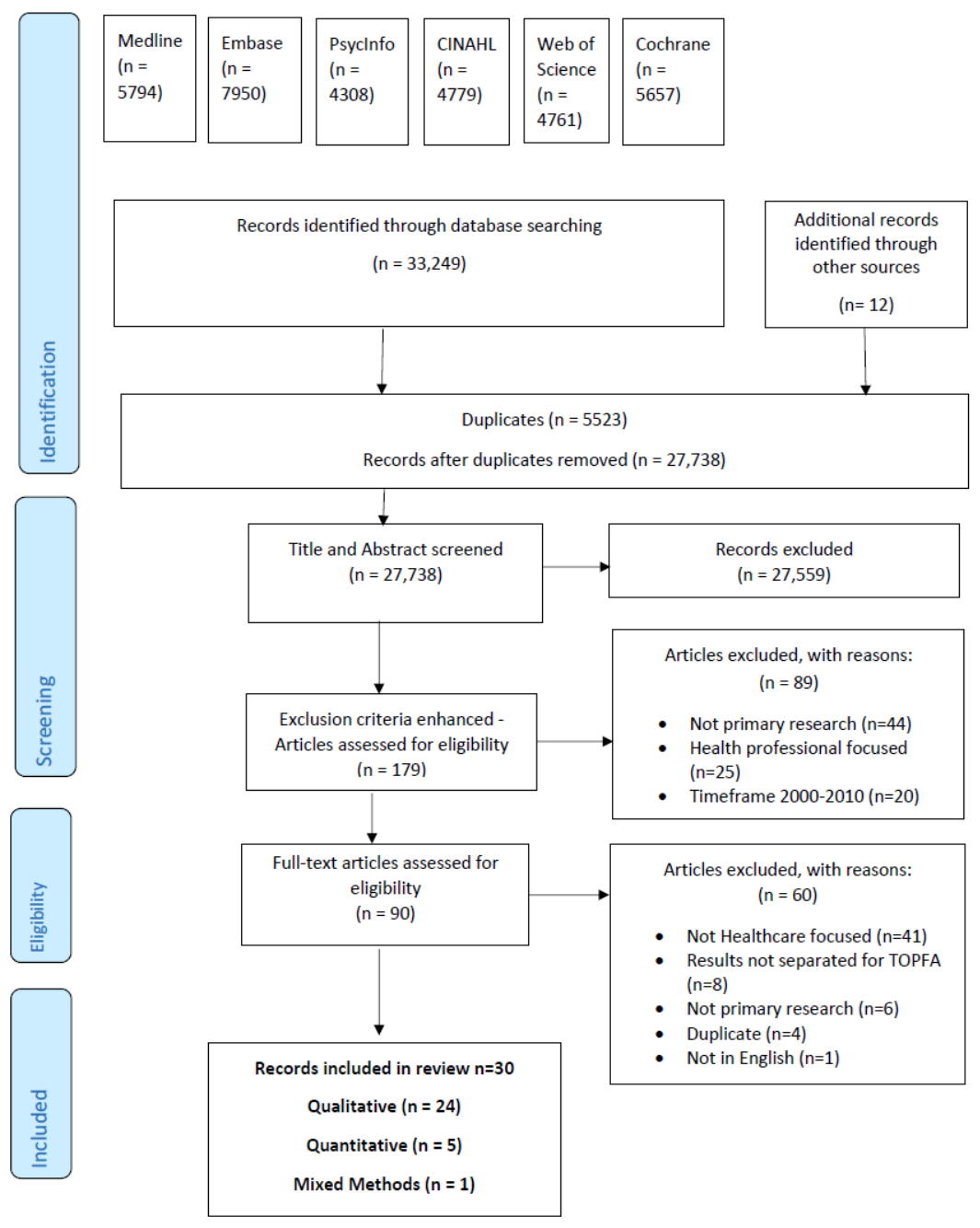

\section{Figure 1}

Search strategy and identification of records included in this review

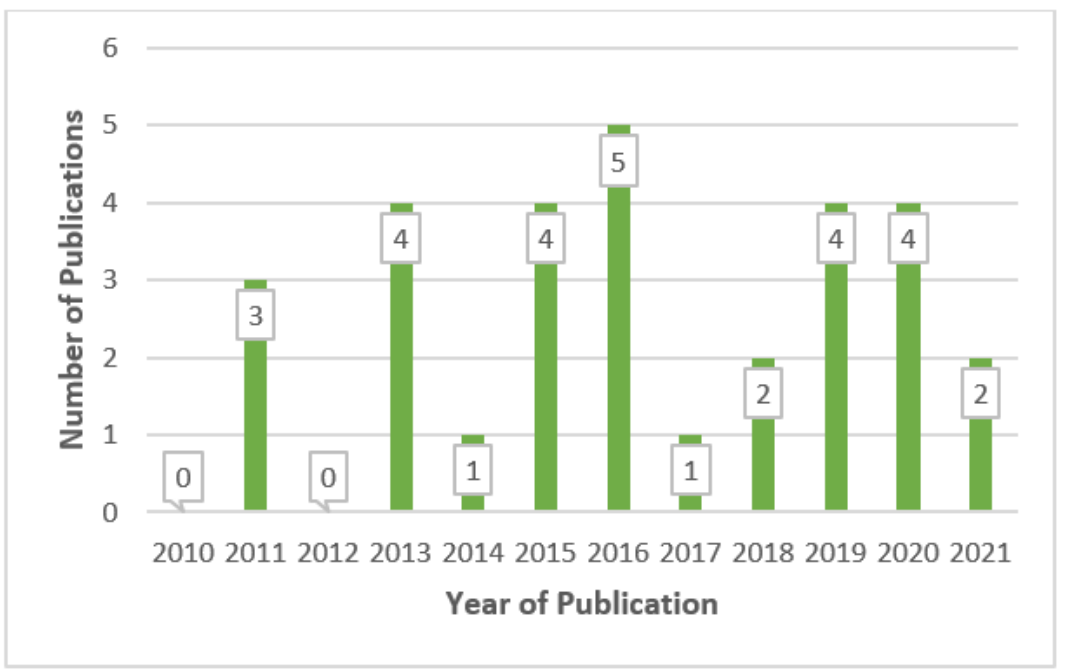

Figure 2

Year of Publication 